\title{
Economic Regulation and Corporate Governance: The Case of Wirecard
}

\author{
Frederick Betz' ${ }^{1}$ Michael Kim² \\ ${ }^{1}$ Institute for Policy Models, Seattle, WA, USA \\ ${ }^{2}$ Department of International Business, Keimyung University, Keimyung University, Daegu, South Korea \\ Email: fbetz@venture2reality.com
}

How to cite this paper: Betz, F., \& Kim, M (2021). Economic Regulation and Corporate Governance: The Case of Wirecard. Modern Economy, 12, 1386-1423. https://doi.org/10.4236/me.2021.129072

Received: August 9, 2021

Accepted: September 26, 2021

Published: September 29, 2021

Copyright (c) 2021 by author(s) and Scientific Research Publishing Inc. This work is licensed under the Creative Commons Attribution International License (CC BY 4.0).

http://creativecommons.org/licenses/by/4.0/ (c) (i) Open Access

\begin{abstract}
An important normative theory in economics is that all markets are perfect-perfect in the sense that "prices" in a market should be set by balancing "demand" against "supply". Certainly, this is a desirable theory, by reducing government interference in pricing in a market to leave economic interactions as principal forces-particularly so in financial markets. But in reality, this desirable theory does not do away with government regulation, because markets can be corrupted or misused (and this has sometimes been called "market imperfections"). Empirically in economic history, money has sometimes been made by economic agents in a market through using corruption or misuse of market forces. Thus, as an empirical reality in economic systems, the need for regulation always exists. This research analyzes an actual case of market corruption on an international scale, the Wirecard scandal. We analyze this empirical case to expand regulatory theory by investigating the kind of roles needed to be played by some market forces (e.g. government regulators, corporate auditors, and financial reporters) in order for "imperfections" of financial markets to be avoided or corrected.
\end{abstract}

\section{Keywords}

Regulatory Economics, Market Imperfections, Corporate Law, Corporate Governance, Corporate Performance, Corporate Integrity, Corporate Auditing, Securities Regulation, Global Corporations, Financial Reporting

\section{Introduction}

Regulatory theory crosses the disciplines of economics, corporate law, and management science. In economics, the term "regulatory economics" focuses upon the control by government over corporate activities in accountability, safety, and 
monopoly power. In corporate law, regulation focuses upon accountability and responsibility to shareholders. One of the differences between the two perspectives of economics and of law is based upon two different hypotheses. Traditional economics assumed that "markets-are-perfect" and that government control is probably harmful to market efficiency. In contrast, corporate law focused on corporate power, particularly protecting shareholder interests through transparency of information. Management science has focused on efficiency in organizational operations and leadership.

In any social science theory, explanations can be normative or empirical. Normative explanations are prescriptions of what-ought-to-be; whereas empirical explanations are descriptions of what-really-is. Methodologically about social science theory, this has been called "Idealism versus Realism" in explanation.

In the realism of a historical event, any normative explanation from the social sciences is often contradicted by what really happened in the historical event. What we are doing in this research is to analyze a historical event which diverged from proper corporate regulation-in order to provide empirical grounds for validation of theoretical hypotheses about "market perfection" and "corporate transparency"-occurring in the reality of stock market action. The case of "Wirecard" is an empirical event in modern economic history.

\section{Economic Case History: Wirecard Fraud}

Wirecard was a German-based international corporation, in business as an Internet payment processor. Wirecard filed for bankruptcy on 25 June 2020, due to exposure of financial fraud. The actual performance of the company was only revealed late in its decade-long history-and only after whistleblower complaints and a newspaper investigation. Part of the scandal was that the German securities regulatory agency, Federal Financial Supervisory Authority (BaFin), had been derelict in its regulatory duties over Wirecard, for several years. BaFin failed to properly investigate Wirecard's performance, allowing a corporate scam to go uncovered.

Only later was it discovered by a newspaper investigator that 1.9 billion euros were "missing" from Wirecard's accounts. Then the CEO of Wirecard was arrested. Liz Alderman and Christopher Schuetze wrote: "Markus Braun, the former chief executive of Wirecard (a German electronic payment platform) has been arrested in Munich on 25 June 2020. The company admitted that the 1.9 billion euros ( $\$ 2.1$ billion) missing from its accounts probably 'do not exist.' Markus Braun, who resigned as chief executive on Friday, traveled from his home in Vienna to Germany late Monday and turned himself into the authorities. Earlier on Monday, the Munich state attorney had filed a petition for an arrest warrant on suspicion of market manipulation.” (Alderman \& Schuetze, 2020a)

Wirecard had been founded in 1999 but came close to bankruptcy in 2002, when Markus Braun injected capital and became the CEO. Braun focused Wire- 
card on providing internet payment services. Earlier Braun had graduated from the Technical University of Vienna with a degree in commercial computer science. In 2000, he earned a $\mathrm{PhD}$ in social and economic sciences from the University of Vienna and also worked as a consultant at Contrast Management Consulting GmbH. From 1998 to 2001, Braun worked as a consultant KPMG Consulting AG. And in 2002, Braun next became CEO of Wirecard.

Wirecard began a rapid expansion of services in 2007. And in 2007, Wirecard was providing payment services for a tour operator TUI and later in 2014 for KLM Royal Dutch Airlines. Also in 2014, Wirecard offered a "Checkout Portal" for online purchases in retailers. Also in 2007, Wirecard had expanded in Asia in Singapore. In 2014, Wirecard expanded into New Zealand, Australia, South Africa, and Turkey. In 2016, Wirecard acquired a South American Internet payment service provider in Brazil. In 2014, Wirecard had offered its "Checkout Portal" as a fully automated application for easily connecting different payment methods in online shops, with a focus on SMEs and virtual marketplaces. Next in 2015, Wirecard provided a mobile-payment-app, it called "Boon". It was a virtual Mastercard running on either Android or IOS phone operating systems.

During these early years, Wirecard looked successful, and Wirecard's rapid growth had made its CEO famous. Liz Alderman and Christopher F. Schuetze wrote: "In the elite corridors of corporate Germany, Markus Braun had become a legend. A little-known entrepreneur until just a few years ago, Mr. Braun had forged an obscure Bavarian company called Wirecard into a German tech icon, winning a coveted spot on the benchmark DAX stock index in Germany. Wirecard provided the invisible financial plumbing that, with a wave of plastic over a card reader almost anywhere in the world, made transactions happen. Hedge funds and global investors scrambled to buy shares." (Alderman \& Schuetze, 2020a)

But its supposedly rapid growth had not been real. Liz Alderman and Christopher Schuetze wrote: "When critics raised red flags about the company's seemingly miraculous success, questioning murky accounts and income that could not be traced, Mr. Braun, an executive from Austria who was the company's biggest shareholder, hit back repeatedly, and the stock price skyrocketed. But on Thursday (June 25), Mr. Braun's empire came crashing down after Wirecard filed for insolvency proceedings, days after the financial technology company acknowledged that 1.9 billion euros ( $\$ 2.1$ billion) that it claimed to have on its balance sheets probably never existed. Its longtime auditor, EY (formerly known as Ernst \& Young) said the company had carried out 'an elaborate and sophisticated fraud.' Mastercard and Visa said Friday that they were considering cutting ties." (Alderman \& Schuetze, 2020a)

Wirecard's rapid rise in the German stock market was due to a perception that Wirecard services were growing worldwide, particularly in Asia. Yet problems had emerged about Wirecard's operations. Olaf Storbeck wrote: “But in 2018, a KPMG audit showed that activities under the company's direct control yielded 
$€ 74 \mathrm{~m}$ in operating losses, compared with losses of $€ 3 \mathrm{~m}$ a year earlier. This loss was masked by profits attributed to outsourced activities in Asia, where Wirecard said it relied on third-party business partners because it did not possess its own licenses to operate. Now in 2020, these outsourced activities are at the center of an accounting scandal that has rocked German finance. Wirecard warned investors last month that this part of the business may not have 'actually been conducted for the benefit of the company' and was misrepresented to investors. But the activities outside Asia have failed to generate a profit since 2016, when it made $€ 20 \mathrm{~m}$, contributing just 8 per cent to group earnings before interest and tax. The poor operating performance outside Asia highlights the challenges facing Wirecard's administrator in finding buyers for the remaining business." (Storbeck, 2021a)

In 2020, Wirecard's shares fell in value when its auditor EY finally found that its previous audits of Wirecard were in error. Kevin Granville wrote: "Shares of Wirecard have fallen 90 percent over the last week after the company's auditor, EY, refused to sign off on its 2019 annual report. That prompted Markus Braun, Wirecard's longtime chief executive, to step down last Friday. He was then arrested this week by Munich authorities on suspicion of market manipulation. After his arrest, Mr. Braun was released on bail of 5 million euros." (Granville, 2020)

Wirecard went into bankruptcy, triggered by reporting in the Financial Times. Liz Alderman and Christopher Schuetze wrote: "When the reports emerged of suspected wrongdoing at Wirecard, Mr. Braun and his team responded by delaying EY's annual report for 2019 and hiring KPMG to provide an independent assessment of the company's books. In its report, released in April, KPMG said it could not provide sufficient documentation to address all allegations of irregularities. In the most serious finding, covering 2016-18, KPMG said it had been unable to verify the existence of $€ 1$ billion in revenue that Wirecard booked through three obscure third-party acquiring partners. The findings led to calls by some investors for Mr. Braun's ouster. The KPMG report then attracted the attention of Germany's financial regulator, BaFin, which had previously prevented short-sellers from manipulating Wirecard's stock price. On June 5, prosecutors raided the company's headquarters and opened proceedings against management as part of the inquiry initiated by BaFin. Prosecutors said in a statement that the company was suspected of releasing misleading information that may have affected Wirecard's share price." (Alderman \& Schuetze, 2020b)

\section{Methodology}

For the social science disciplines to use societal histories as the basis for scientific empiricism, a historical event needs to be analyzed in terms of the societal factors generalizable from one historical event to another. In this research, we analyze a historic case of corporate fraud in the German stock market. This case provides empirical evidence about the validity and depth of current theory in 
corporation practice and law.

The methodological parallel (to basing social science theory on historical examples of societal events) is in the physical science disciplines the research technique of analyzing all physical phenomena as observations in physical space/time. (e.g., a physical event is observed as motion of an object through space and over time.) To scientifically describe a change event in a society's history (historical event), the social sciences (including economics and law) need an analogy to the physical perceptual space-an analogy but a different kind of perceptual space-a functional space for observing functional phenomena. Such a general societal-function space has been constructed from three of basic dichotomies in the disciplines of social sciences: individual-society, groups-processes, reason-action (Betz, 2011).

The first basic idea in the social sciences literatures is that every social science discipline distinguishes between individuals and the society in which they live-the dichotomy of individual \& society. For example, in economics, this dichotomy is called-an "economic agent" and an "economic market". In management science, this dichotomy is called a "manager" and an "organization". In psychology, this dichotomy is called an "individual" and a "society". In anthropology, this dichotomy is called an "individual" and a "culture".

The second basic idea in the social sciences distinguishes within a society how individuals associate into groups within a society and the processes a group inculcates in members-the dichotomy of group \& process. A social process is a series of actions coordinated to produce an outcome planned by a group. For example, in economics, this dichotomy distinguishes between a "financial institution" and a "financial process". In sociology and in management science, this dichotomy distinguishes between "masses/groups/corporations" and "operations". In anthropology, this dichotomy distinguishes between "culture" and "traditions".

The third basic idea found in the social sciences is about individuals and their behavior in society. Individuals are described as sentient (or cognitive) beings acting according to perceived reasons-the dichotomy of action \& reason. For example, in economics, this dichotomy distinguishes between economic transactions and economic rationality. In management science, this dichotomy distinguishes between "implementation" and "strategy". In psychology, this dichotomy distinguishes between "behavior" and "rationalization".

These three dichotomies have been used to construct three-dimensional societal-event space in which to analyze the historical activities in terms of six basic factors (individual-society, groups-process, and action-reason (Betz, 2011). This is graphically shown as a three-dimensional societal-event perceptual space, Figure 1.

In any historical event, the event can be generally analyzed in these six factors and interactions between them. To conveniently describe the analysis of events in the social-science perceptual space, one can show the areas around the dimensional axes as a kind of historical event-box-in Figure 2. 


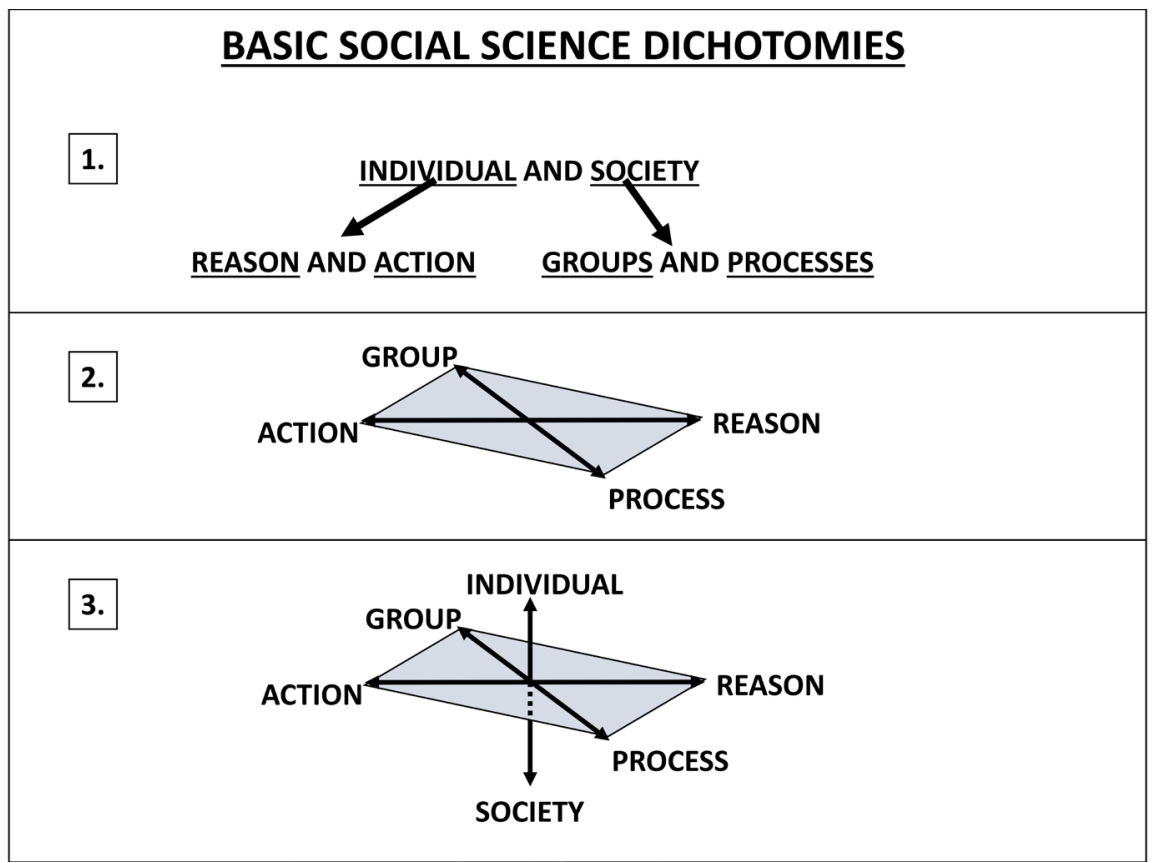

Figure 1. Observational space for analyzing historical change events in a societal structure.

SOCIETAL PERCEPTUAL-SPACE EVENT BOX

INTERACTIONS OF (INDIVIDUAL \& SOCIETY) ARE MEDIATED BY (REASON \& ACTION) THROUGH (GROUPS \& PROCESSES)

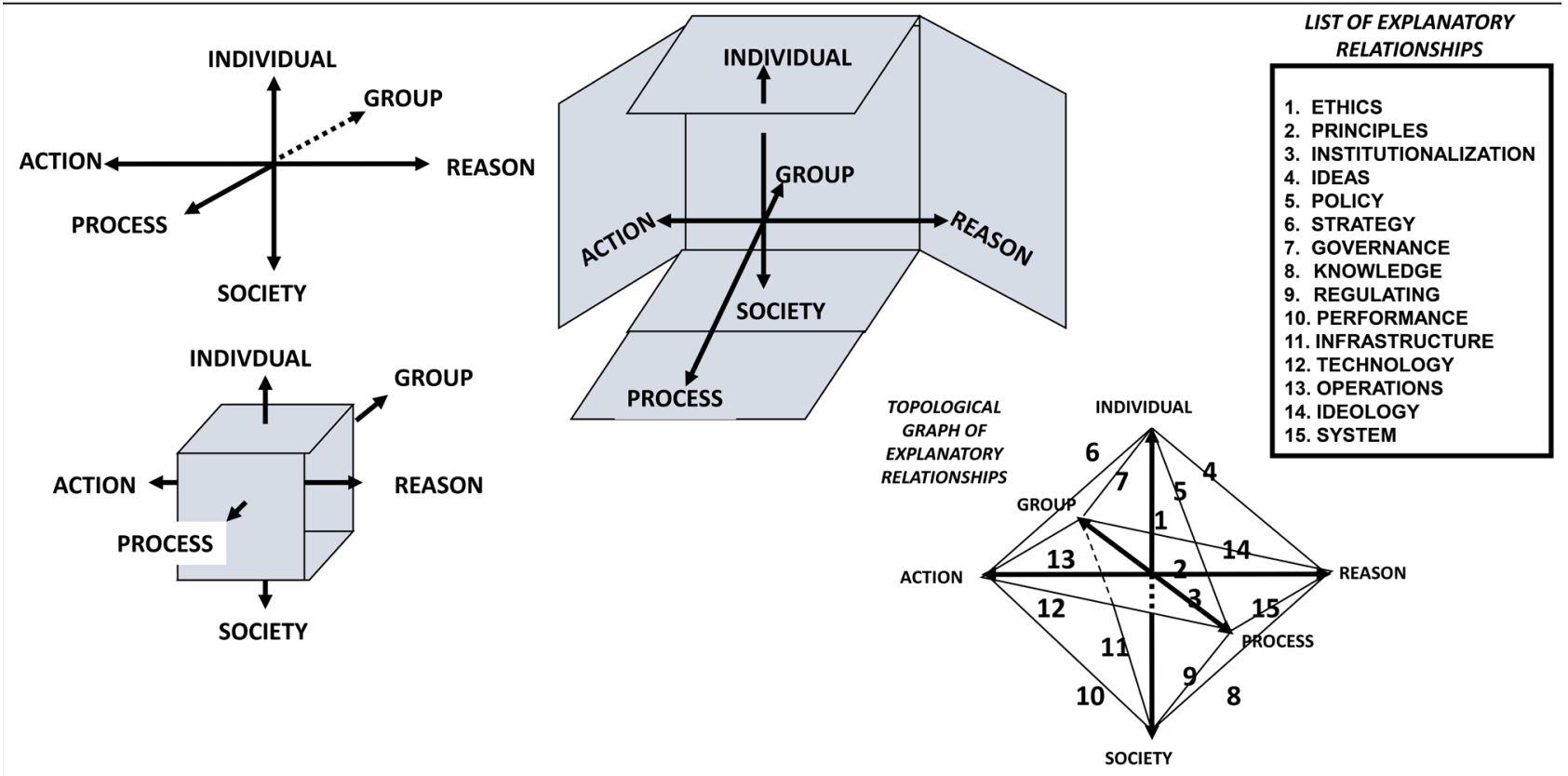

Figure 2. Societal perceptual space event box with 15 topological explanations.

A note on the research methodology shown in Figure 2.

The construction of a three-dimensional observational space for analyzing historical events in a society facilitates the abstraction of important (significant) societal factors occurring in the event. The six factors are: 
The Individuals involved in the event, and the Society in which the event occurs.

The Groups involved in the event, and the Processes in the event used by the groups.

The Actions that occur in the event, and the Reasoning by Individuals and Groups about these actions.

To highlight the factors in a historical event, one can build a box around the axis-arrows, in order to have surfaces for conveniently listing the factors which happened in the event. Since this box is three dimensional, opening up the box shows all surfaces in one view.

As an additional analytical tool to explanation occurrences in the event, one can next construct a topological graph of this 3-dimentional space. This topological graph shows the connections between any two factors in an event. Since the concept of "explanation" connects two factors in an observation, this graph shows that there are 15 possible functional explanations, in a societal event. The list of the 15 kinds of explanations is shown in Figure 2. One can find the derivation of the explanations in the reference (Betz, 2011).

An event box provides an analytical technique for abstracting and summarizing the key factors in the societal change event (historical event which changes structure-function in a society).

Expressing the connections between the key factors provides a graphical model of the kinds of explanations which can analyze the change event-fifteen possible explanations in the historical event (of why the history occurred).

This analysis of a historical event facilitates the abstraction of generalizable explanations out of the descriptive complexity of the event.

We will use this research technique to analysis the Wirecard scandal-a failure in a stock market due to improper auditing and regulation. As shown in Figure 3, we apply the analytical technique of a societal dynamics event analysis to summarize the key societal factors and explanations in the Wirecard historical event.

INDIVIDUAL-Markus Braun was the chief executive of Wirecard, having grown the company to international recognition; but later he was arrested in Munich on 25 June 2020 for fraud in Wirecard.

SOCIETY-The society was the German nation and the international market.

GROUP-The group in the event was a company called Wirecard and German regulator, BaFin, and auditing group EY.

PROCESS-The business process of Wirecard provided an Internet payment platform in different countries.

REASON-Wirecard told its auditor and German regulator that it had more sales than it really had and listed a billion dollars in profits it didn't have.

ACTION-Markus Braun was accused of fraud in the operation of Wirecard 


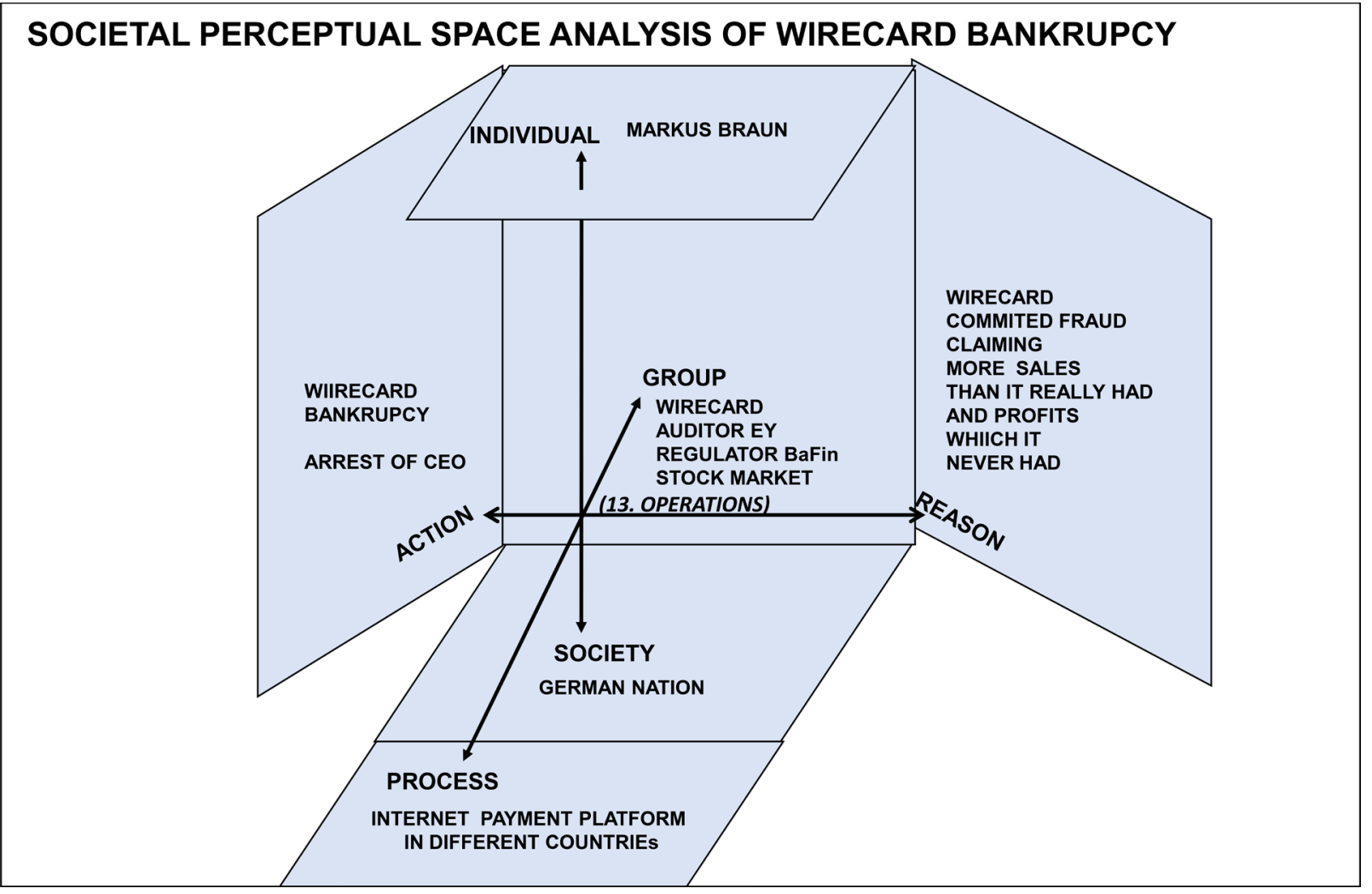

Figure 3. Analysis of Wirecard Bankruptcy in 2020.

and was arrested in Munich, Germany, on 25 June 2020. Wirecard then declared bankruptcy.

This analysis highlights how the bankruptcy of Wirecard occurred. The $A c$ tion in the event was bankruptcy triggered by the Individual Markus Braun as CEO of the company, which was listed on the stock market of the German Society. The Reason for the bankruptcy was deception by the CEO about the profitability of the company's operations. The CEO published profits which did not in fact exist, as Wirecard as an Internet payment Process failed to create customers and sales. The Groups involved in the historical event were the company Wirecard, the auditors for Wirecard and the regulatory agency over the German stock market.

\section{Historical Case (Continued): Wirecard Operations}

It turned out that the reason that Wirecard was not successful at its payments business was that its operations were neither efficient nor effective. Olaf Storbeck wrote: “It was Wirecard's biggest deal-and its most controversial. In October 2015, the German technology company agreed to pay up to $€ 340 \mathrm{~m}$ for a collection of small, barely profitable Indian payment groups. Two of the companies, Hermes I Tickets and GI Technology, had been involved in processing payments for just a couple of years. Wirecard chief executive Markus Braun hailed the deal, saying at the time that it would strengthen the company's position in one of the world's 
most rapidly growing electronic payment markets... The companies were sold to Wirecard by an entity based in Mauritius called Emerging Markets Investment Fund 1a (EMIF1a), which was only incorporated in February of that year. EMIF1a had bought the Indian companies six weeks earlier for a fraction of the price. The ultimate beneficial owners of the Mauritius entity, which reaped profits from selling the payment groups to Wirecard, have remained a mystery... For years, questions have lingered over whether one or more Wirecard executives were behind EMIF1a...” (Storbeck, 2021b)

Markus Braun was chief operating officer (CEO) of Wirecard, and Jan Marsalek was the chief operating officer (CEO) of Wirecard, and apparently he had encouraged the purchase of EMIF by Wirecard. Olaf Storbeck wrote: "According to emails reviewed by the Financial Times, Marsalek (Wirecard manager) was introduced to the co-founders of the payment groups by Henry O'Sullivan, a British businessman who advised Wirecard in Asia and entered at least one partnership with the company in the region. The Briton was among those believed to have controlled EMIF1a... It was in late 2014 that O'Sullivan put Marsalek in touch with Palani Ramasamy, who with his brother Ramu had co-founded Hermes and GI Technology. ... Marsalek met Palani Ramasamy in December 2014 at Vienna’s Hotel Sacher. In March 2015, Marsalek began redesigning the website of Hermes. Wirecard's former chief operating officer commissioned a Munich-based designer, provided pictures and text, and personally oversaw the work. Hermes was equipped with a state-of-the-art website, and both Hermes and GI Technology were given modern logos... Emails show that Wirecard footed the bill for the revamp, about $€ 25,000$. Weeks after the new Hermes site went online, Wirecard began the takeover talks with EMIF 1a. Dubbed 'Project Peacock' within Wirecard, Marsalek was keen to get the deal done quickly... But it appears that Wirecard may have vastly overpaid EMIF 1a for the Indian companies. In the days leading up to Wirecard's implosion, an internal restructuring team put the value of GI Technology at zero, according to a presentation seen by the Financial Times." (Storbeck, 2021b)

Marsalek, who encouraged Wirecard to purchase EMIF1a, may also have owned an interest in EMIF. Olaf Storbeck wrote: "In early 2016, a Wirecard employee based in India told EY auditors that 'senior executives' of the German payments group (Wirecard) directly or indirectly held stakes in EMIF1a.... Early last year, EY's anti-fraud team suggested that Marsalek might be one of the owners-an allegation he vehemently denied. Mauritian regulators suspended the fund's license after Wire-card's collapse.... Marsalek absconded in June last year and is on Interpol's most-wanted list." (Storbeck, 2021b)

Also Wirecard's business growth in Asia was a fraud. Wirecard reported business revenue it never earned nor obtained. Some of Wirecards' employees "cooked-the-books". One of these employees was an Indonesian, who ran accounting and finance for Wirecard in Asia. Dan McCrum and Stefania Palma wrote: "A preliminary report by a top law firm has unveiled a pattern of suspected book-padding across the group's Asian operations. Edo Kurniawan, a 
jovial 33-year-old Indonesian who runs the Asia-Pacific accounting and finance operations for global payments group, Wirecard AG, called half a dozen colleagues into a Singapore meeting room. He picked up a whiteboard pen and began to teach them how to cook the books... He said the task at hand was to create figures that would convince regulators at the Hong Kong Monetary Authority to issue a license so Wirecard could dole out prepaid bank cards in the Chinese territory of Hong Kong... The group was seeking to take over payment operations from Citigroup, covering 20,000 retailers in 11 countries stretching from India to New Zealand. Regulatory approvals in every territory were crucial, even if it meant inventing numbers to be used in the Hong Kong license application." (McCrum \& Palma, 2019)

The problem for Wirecard was that it needed a license in each nation in Asia to operate in that nation. Wirecard was having problems with Hong Kong authorities who would not issue a license to operate in China. Dan McCrum and Stefania Palma wrote: "Mr. Kurniawan then sketched out a practice known as 'round tripping'. A lump of money would leave the bank Wirecard owns in Germany, show its face on the balance sheet of a dormant subsidiary in Hong Kong, depart to sit momentarily in the books of an external 'customer', then travel back to Wirecard in India, where it would look to local auditors like legitimate business revenue." (McCrum \& Palma, 2019)

The employee was proposing to "cook" Wirecard's accounts with revenue that did really come in-but was only Wirecard's money circulating around in accounts and back to Wirecard. Publicly calling this a business income is "fraud". But was the employee secretly doing this on his own or did upper management know about this? McCrum and Stefania Palma wrote: "Mr. Kurniawan's scheme might have appeared to be the act of a rogue employee in the provincial outpost of a little known financial group. But the account of what happened, in a preliminary report on the investigation by one of Asia's most eminent legal firms, indicated it was part of a pattern of book-padding across Wirecard's Asian operations over several years" (McCrum \& Palma, 2019)

Apparently the senior executives did know about the scheme. Dan McCrum and Stefania Palma wrote. "Documents seen by the Financial Times show two senior executives in the Munich head office had at least some awareness of the round-tripping scheme: Thorsten Holten and Stephan von Erffa, respectively the company's head of treasury and head of accounting." (McCrum \& Palma, 2019)

In addition, some business associates of Wirecard assisted Wirecard in its fraud. Stefania Palma, Olaf Storbeck, and Dan McCrum wrote: “A Singaporean businessman with multiple ties to Wirecard has been charged with falsification of accounts, marking the first set of charges issued by the city-state since it kicked off an investigation into the collapsed German payments company last year. R Shanmugaratnam is suspected of being a key figure in an alleged multi-year fraud, accused of playing the role of trustee for fake bank accounts, which Wirecard told auditors were filled with cash. Wirecard collapsed into insolvency 
in June after it admitted that $€ 1.9$ bn of cash in so-called trustee accounts probably did 'not exist'.... Singapore police last month charged Mr. Shanmugaratnam with falsifying 'willfully and with intent to defraud' letters to Wirecard saying that his company, Citadelle Corporate Services, was holding hundreds of millions of euros in escrow accounts 'when in fact [they] did not hold such balance', according to charge sheets. Mr. Shanmugaratnam, a Singaporean, was accused of forging three letters in March 2016 and one a year later, claiming Citadelle was holding a total of $€ 321 \mathrm{~m}$ in three separate escrow accounts. If convicted, Mr. Shanmugaratnam could face up to 10 years in prison and a fine for each of the four charges." (Palma, Storbeck, \& McCrum, 2020)

Also, it turned out that Wirecard's fraudulent tendencies were not new. Wirecard's upper management had even been stealing from Wirecard-for a long time. Olaf Storbeck wrote: 'Wirecard's fraud started more than a decade before the German payments company imploded, when some senior managers began establishing a network of offshore companies that were used to siphon off millions of euros, a former top executive has told prosecutors. Oliver Bellenhaus has informed Munich prosecutors that starting in 2010 he created an array of shell companies based in Hong Kong and the British Virgin Islands, according to people with knowledge of the matter. He said that he did so at the behest of Jan Marsalek, Wirecard's former chief operating officer who is now on Interpol's most wanted list... Bellenhaus has told prosecutors that from 2011, he and Marsalek shifted funds out of Wirecard and into bank accounts in the name of the shell groups. Some years later, Bellenhaus moved millions of these funds to a private foundation." (Storbeck, 2021c)

Markus Braun, the head of Wirecard, denied involvement in those thefts. Storbeck wrote: "Munich prosecutors have used testimony from Bellenhaus to build a prosecution case. They accuse Wirecard's former chief executive Markus Braun of being the linchpin of a criminal racket that allegedly inflated Wirecard's revenue in an attempt to deceive investors. Braun denies any wrongdoing. The former chief, who also was Wire-card's single largest shareholder, last summer said the company had been the target of 'fraud of considerable proportions'. In November, he told MPs that he hoped prosecutors would succeed in tracing the missing money." (Storbeck, 2021c)

The amounts of cash stolen from Wirecard were large. Olaf Storbeck wrote: "Wirecard employees hauled millions of euros of cash out of the group's Munich headquarters in plastic bags over many years... The practice started as early as 2012, with six-digit sums in banknotes often moved in Aldi and Lidl plastic bags, former staff told the police... As demand for cash grew over time, Wirecard Bank bought a safe located in the group's headquarters in a Munich suburb. At one point in May 2017, €500,000 in cash was delivered when the safe was full, according to emails seen by the FT. Some of the cash was hidden elsewhere in the offices.... An employee, who worked at the headquarters for almost two years until 2018, told police that amounts of $€ 200,000$ - $€ 700,000$ were removed fre- 
quently, sometimes several times a week, according to people familiar with the investigation. That suggests more than $€ 100$ m could have been removed." (Storbeck, 2021c)

The theft of money by Wirecard employees continued up to the final weeks of Wirecard. Olaf Storbeck, Richard Milne, and Stefania Palma wrote: "Prosecutors suspect that a Lithuanian payments company, Finolita, was used to steal more than $€ 100 \mathrm{~m}$ from Wirecard weeks before it collapsed, with some of the money channeled to the German group's fugitive second-in-command Jan Marsalek... Prosecutors suspect that part of a $€ 100 \mathrm{~m}$ loan granted by Wirecard in March 2020 to a subsidiary of Finolita's owner, and processed by the Lithuanian company, was channeled to Marsalek, Wirecard's former chief operating officer who is wanted by Interpol.” (Storbeck, Milne, \& Palma, 2021)

Beginning in 2017, real information about Wirecard's operations began to leak out, due to a "whistle-blower", Pav Gill. Gill had been hired by Wirecard as an in-house lawyer for the Asian operations. Dan Mccrum, Stefania Palma, and Olaf Storbeck wrote: "Gill was hired in September 2017 as Wirecard's first in-house lawyer responsible for the Asia-Pacific region, reporting directly to Munich. Within months he was approached by two Wirecard employees who accused colleagues of cooking the books.” (Mccrum, Palma, \& Storbeck, 2021)

Gill began an internal investigation into Asian operations: Dan Mccrum, Stefania Palma, and Olaf Storbeck wrote: "A probe was launched, codenamed Project Tiger, that focused on a young Indonesian, Edo Kurniawan, whom Gill described as Wirecard's 'third most important finance and accounting employee globally'. Gill found it odd that someone with as little experience as Kurniawan held such an important job. He recalls that Kurniawan regularly flew to Munich for meetings, but at the time, Gill's focus was on Asia. 'I don't think anyone at the initial stage thought the entire company was diseased,' he said. An outside law firm, Rajah \& Tann, was hired to investigate and copies were taken of Kurniawan's email inbox on the authority of Daniel Steinhoff, then Wirecard's deputy general counsel responsible for compliance. In that trove of data lay evidence of the fake customers behind Wirecard's facade. 'Nothing would have happened if we hadn't had the go-ahead by Steinhoff,' Gill said. The investigation, Project Tiger, quickly uncovered misconduct. Staff were emailing themselves logos, faking contracts and invoices.” (Mccrum, Palma, \& Storbeck, 2021)

The legal staff had not engaged in the fraudulent activities, and their probe began to uncover suspicious activity. But the top management of Wirecard made no move to stop the fraud. Instead, they stopped the investigation. Dan Mccrum, Stefania Palma, and Olaf Storbeck wrote: "Wirecard top brass took no action against the suspected perpetrators. Instead, Jan Marsalek seized control of the probe. Gill was shocked. 'Any normal company, especially a listed company, would have suspended these people, even if it was just for show." (Mccrum, Palma, \& Storbeck, 2021)

Pav Gill found that top management really did not appreciate his efforts to 
identify the internal fraud. Dan Mccrum, Stefania Palma, and Olaf Storbeck wrote: "As the months progressed, Gill's job became untenable. In September he was presented with a choice: resign with a positive reference or be fired. Gill lacked the strength or resources to fight, and felt out of options... In October 2018, Gill was forced out of Wirecard, after executives had stonewalled an internal investigation into fraud allegations." (Mccrum, Palma, \& Storbeck, 2021)

But the Wirecard's impact upon Gill's career did not stop there. Wirecard management pursued him. And finally, Pav Gill talked to Financial Times reporters. Dan Mccrum, Stefania Palma, and Olaf Storbeck wrote: "Gill said, 'they tried to destroy me, manfully, professionally, emotionally'. He suspected he was being followed. Neighbors reported strange men taking an interest in his flat. Bad references were paid to his job prospects. Some job interviews felt like traps to lure him into breaking his non-disclosure agreements, with an excessive focus on the reasons he left Wirecard... In 2018, the reluctant Gill decided that for the fraud to be properly exposed, he had to be involved. In encounters in out-of-the way coffee shops and Singapore hotel lobbies, he explained to the Financial Times what had happened to him... For Gill, the Financial Times played a role. 'It felt like a burden was lifted. It's no longer you who carries the weight of that information.' The first story took nerve-racking months to appear. When it did, Wire-card called it 'another inaccurate, misleading and defamatory media report'. A few days later, then chief executive Markus Braun changed tack, admitting the gist but attacking the source." (Mccrum, Palma, \& Storbeck, 2021)

\section{Corporate Case History (Continued): Auditing Wirecard}

Yet over the years of 2016, 2017, 2018, the auditors of Wirecard, the accounting firm Ernst \& Young Global Limited (EY) had audited Wirecard's performance and had suspected nothing. EY's audits were, in fact, faulty.

Olaf Storbeck, Tabby Kinder, and Stefania Palma wrote: "Ernst \& Young Global Limited (EY) failed for more than three years to request crucial account information from a Singapore bank where Wirecard claimed it had up to $€ 1$ bn in cash - a routine audit procedure that could have uncovered the vast fraud at the German payments group. The accountancy firm, which audited Wirecard for a decade, has come under fire after the once high-flying financial tech company filed for insolvency this week, revealing that $€ 1.9$ bn in cash probably did 'not exist'. People with first-hand knowledge told the Financial Times that the auditor between 2016 and 2018 did not check directly with Singapore's OCBC Bank to confirm that the lender held large amounts of cash on behalf of Wirecard. Instead, EY relied on documents and screenshots provided by a third-party trustee and Wirecard itself." (Storbeck, Kinder, \& Palma, 2020)

The false information about sales and profits were large amounts. Olaf Storbeck wrote: "According to its EY-audited financial reports, between 2016 and 2018 Wire-card generated operating margins of around 22 per cent and almost doubled annual earnings before interest and taxes to $€ 439 \mathrm{~m}$. The company last 
year in 2018 also promised investors a fivefold increase in profits by 2025. But such profits appear to have existed largely on paper, according to data in the confidential appendix of a special audit conducted by KPMG and seen by the Financial Times... Wirecard's internal numbers reveal that the operating performance of its core business-mainly payments processing in Europe and issuing credit cards in Europe and North America-was far worse than previously known. The figures show that those activities have also become increasingly lossmaking, despite accounting for half the company's reported revenue and almost two-thirds of transaction volumes." (Storbeck, 2021d)

For several years, Wirecard had not been making profits, while claiming to be very profitable. Wirecard was really losing money. Olaf Storbeck wrote: "Later KPMG's special audit showed that profits existed largely on paper, with Wirecard's Asia units being lossmaking since 2016. The KPMG special audit was launched last year in 2019. EY, the group's original auditor, reported that earnings almost doubled from 2016 to 2018. But really, Wirecard's core business in Europe and the Americas was lossmaking for years, casting doubt on the economic substance of the parts of the company not directly affected by its accounting scandal." (Storbeck, 2021d)

The accounting firm EY had failed in its accounting responsibility; and later another accounting firm KPMG had performed an accurate audit. Why had EY not done its proper job? Olaf Storbeck, Tabby Kinder, and Stefania Palma wrote: "A senior banker at a lender with credit exposure to Wirecard said, 'The big question for me is what on earth did EY do when they signed off the accounts?' A senior auditor at another firm said that obtaining independent confirmation of bank balances was 'equivalent to day-one training at audit school'." (Storbeck, Kinder, \& Palma, 2020)

This was a scandal in international accounting firm's performances. Olaf Storbeck, Tabby Kinder, and Stefania Palma wrote: "A 'Big Four' accounting firm, EY, had issued unqualified audits of Wirecard for a decade despite-increasing questions over suspect accounting practices from journalists and short sellers." (Storbeck, Kinder, \& Palma, 2020)

It turned out that in 2016, Wirecard's attempts to generate payments business in Asia had not succeeded. But Wirecard lied about this. Olaf Storbeck, Tabby Kinder, and Stefania Palma wrote: "The accounts at Asian banks play a pivotal role in Wirecard's accounting fraud that culminated in the group filing for insolvency. According to the company's former management, the accounts were used to settle transactions with partners who acted on Wirecard's behalf in countries where it did not have its own licenses to process electronic payments. Yet it is now unclear if the accounts-let alone the money allegedly deposited there-ever existed." (Storbeck, Kinder, \& Palma, 2020)

Wirecard's lies about Asian business were deliberate, and desperate, to keep the company going. EY argued that it was not its fault that it had not detected the fraud. Later in 2019, after other auditors in EY looked at the situation, EY 
still tried to justify itself. Olaf Storbeck, Tabby Kinder, and Stefania Palma wrote: "In a statement issued on Thursday (March 2020), EY said there were 'clear indications that this was an elaborate and sophisticated fraud, involving multiple parties around the world in different institutions, with a deliberate aim of deception'. The company EY argued that 'even the most robust audit procedures may not uncover this kind of fraud'.” (Storbeck, Kinder, \& Palma, 2020)

But examination of EY's auditing of Wirecard showed poor auding performance not once but over several years. Olaf Storbeck wrote: "EY's audits of defunct payments group Wirecard suffered from serious shortcomings over a period of years, the German investigation found. The Big Four firm is said to have failed to spot fraud risk indicators, did not fully implement professional guidelines." (Storbeck, 2021e)

In Germany, the consequence of EY's poor performance about Wirecard was a loss of other customers. Olaf Storbeck wrote: "Deutsche Bank may drop EY as its auditor after the Wirecard scandal left the Big Four firm under investigation and battling to restore its reputation. In an unusual move, Germany's biggest lender is inviting firms to compete for its 2022 audit just two years after hiring EY to replace KPMG, which had vetted the bank's books for more than 60 years... EY has been under siege since Wirecard collapsed last June 2020 in one of Europe's largest accounting frauds of recent decades... EY billed 580,000 hours to Deutsche during its 2020 audit of the bank." (Storbeck, 2021e)

\section{Case History (Continued): Failure of Regulation by the German Agency (BaFin)}

Wirecard was based in Germany. And in Germany, the Federal Financial Supervisory Authority (BaFin) was the principle regulatory agency for the supervision of German banks and insurance companies and for also for the proper trading of corporate securities. BaFin supervised about 2700 banks, 700 insurance firms, and 800 financial services institutions. BaFin was established in 2002, with the intention to have one agency cover all financial markets in Germany. But when accusations about Wirecard's accounting were made in 2008, 2015, 2016, and 2019. BaFin defended Wirecard, seeing no wrong in it. Then in 2020, Wirecard went bankrupt and its $\mathrm{CEO}$ was arrested. Then BaFin was criticized for failing a proper regulation of Wirecard.

BaFin was run by a Board consisting of the President, Felix Hufeld, and four executive directors: Elisabeth Roegele (securities division), Raimund Röseler (banking supervision), Dr. Frank Grund (insurance supervision), and Beatrice Freiwald (cross-functional areas and internal administration).

In 2021, Guy Chazan and Olaf Storbeck wrote: "Felix Hufeld and Elisabeth Roegele depart as heads of Germany's financial regulator BaFin (Federal Financial Supervisory Authority or Bundesanstalt für Finanzdienstleistungsaufsicht). Hufeld, head of Germany's financial watchdog BaFin, and his deputy Roegele have been pushed out over their handling of the Wirecard scandal, the worst 
accounting fraud in the country's postwar history. In a statement, Olaf Scholz, finance minister, said the Wirecard affair had revealed that Germany's system of financial regulation 'needs to be re-organized, so that it can fulfil its supervisory role more effectively'." (Chazan \& Storbeck, 2021).

Instead of discovering the fraud at Wirecard, the principles in BaFin stood by Wirecard for a long time-before Wirecard's fraud was unveiled. Guy Chazan and Olaf Storbeck wrote: "For months, BaFin has been under fire for ignoring early warnings about fraud at Wirecard, and targeting journalists and short sellers who pointed out misconduct at the payments processor. In April 2019, the watchdog filed a criminal complaint against two Financial Times reporters, triggering an investigation that was only dropped months after Wirecard's collapse. Last year, the European Securities and Markets Authority criticized BaFin for its 'deficient' handling of the scandal." (Chazan \& Storbeck, 2021)

Still the head of BaFin, Mr. Hufeld, defended BaFin's behavior about Wirecard. Guy Chazan and Olaf Storbeck wrote: "In the months that followed (Wirecard's collapse), however, Mr. Hufeld adopted a defiant tone and repeatedly defended BaFin's handling of the affair. The FT revealed this week that he had suggested Wirecard might be the victim of an elaborate plot by short sellers, even after the company itself acknowledged the hole in its balance sheet. Pressure on BaFin has steadily mounted, especially after the German Bundestag last year established a full committee of inquiry into the regulatory failings that allowed the Wirecard scandal to happen." (Chazan \& Storbeck, 2021)

In 2021, the German Federal Ministry of Ministry disclosed that some of BaFin's staff had engaged in private investments, some of which included interest in Wirecard. It was late in 2020 (September) when BaFin finally banned its staff from trading shares and other securities of the companies that it oversees. Guy Chazan and Olaf Storbeck wrote: “Meanwhile, the actions of some of BaFin's staff have also provoked outrage in Berlin. Just this week (in March 2021), BaFin disclosed that it filed a criminal complaint against an employee for insider trading with Wirecard shares in June last year (2020). The FT on Friday also reported that the authorities' decision to ban the shorting of Wirecard shares in 2019 was based on flimsy oral evidence provided by the company itself." (Chazan \& Storbeck, 2021)

In 2021, Hufeld, the head of BaFin, was fired. Guy Chazan and Olaf Storbeck wrote: The German Finance Minister, Mr. Scholz, had initially resisted pressure to ditch the head of BaFin, Mr. Hufeld-focusing instead on a sweeping plan to reform BaFin and so restore confidence in Germany's system of regulation. However, as evidence of regulatory failures at BaFin continued to mount, the finance minister, Scholz, was forced to take more drastic action. In a statement on Friday, Mr. Sholz said that he and Mr. Hufeld had discussed the situation and reached a mutual decision "that, alongside organizational changes, there should also be a change at the top of BaFin". The planned reform of BaFin could only succeed with a "change at the top", Mr. Scholz said (Chazan \& Storbeck, 2021). 
Political pressure from the German parliament had forced the German Finance Minister, Mr. Scholtz, to make changes at BaFin. Guy Chazan and Olaf Storbeck wrote: "Fabio De Masi, an MP for the hard-left Die Linke party, had earlier called Mr Hufeld's departure 'overdue', and said the position of his deputy, Ms Roegele, had also become 'untenable'. As the head of BaFin's securities department, she was behind the controversial decision to ban the short selling of Wirecard shares in 2019." (Chazan \& Storbeck, 2021)

Earlier, the managers of BaFin, Mr Hufeld and Ms Rogele, had even defended Wirecard to the European Union Securities and Market Authority (Esma). Olaf Storbeck wrote: "Documents seen by the Financial Times show that BaFin told Esma that the selling pressure on Wirecard stocks could destabilize the wider German stock market. BaFin gave the Esma selective and incomplete information when making its case for the ban on shorting Wirecard shares.... 'BaFin presented the facts to Esma in a highly distorted way,' Danyal Bayaz, an MP for the Greens, told the Financial Times, adding that the regulator's 'biased arguments' probably tricked Esma into approving the short-selling ban." (Storbeck, 2021f)

Also in 2019, BaFin had tried to take legal action against the newspaper, Financial Times, for reporting in Wirecard's fraud. Olaf Storbeck wrote: "In the year leading to its insolvency, Wirecard raised $€ 1.4 \mathrm{bn}$ of fresh debt which prosecutors think is largely 'lost'. Investors and creditors took the short-selling ban, and a criminal complaint by BaFin against two FT journalists who reported whistleblower allegations against Wirecard, as a vote of confidence for the controversial German company. The investigation against the reporters was only dropped months after Wirecard's insolvency.... In 2020, Esma lambasted BaFin for its 'deficient' handling of the Wirecard scandal. BaFin president Felix Hufeld and his deputy Elisabeth Roegele, who headed the watchdog's securities department, were pushed out last week (in 2021)." (Storbeck, 2021g)

A governmental investigation of the scandal focused upon BaFin's attack on financial reporters. Guy Chazan and Olaf Storbeck wrote: "A key focus of the investigation has been BaFin's controversial decision in February 2019 to impose a ban on the short selling of Wirecard shares, despite misgivings expressed by the Bundesbank, Germany's central bank. 'That... was probably the biggest mistake our authorities made,' says Danyal Bayaz, a Green MP on the committee. 'It was at that moment that they sided with criminals, and investigated journalists and market participants who were posing critical questions.' The Munich prosecutors' role in the BaFin short selling ban has also proved controversial. The chief prosecutor Hildegard Bäumler-Hösl told MPs that two years ago she had a curious phone call with a star Munich lawyer who was working for Wirecard. He told her that Bloomberg reporters had attempted to blackmail the payments company: they purportedly threatened to 'take up an offer from the FT' and publish negative stories about Wirecard, unless it paid them $€ 6 \mathrm{~m}$. Bäumler-Hösl sent a memo to BaFin summarizing the information. Fearing a so-called 'short 
attack' on Wirecard, BaFin then issued its now infamous short selling ban, which appeared to suggest Wirecard's biggest problem was the speculators betting on its falling share price rather than the allegations of fraud swirling round the company. But the blackmail story was a fiction." (Chazan \& Storbeck, 2021)

\section{Historical Case (Continued): German Regulation of Accounting Firm}

The accounting firm EY had failed to properly audit Wirecard and did not detect its fraudulent operations. Accounting firms also need proper oversight. In Germany, accounting firms operating there were overseen by a voluntary regulating committee called the Financial Reporting Enforcement Panel (FREP). Olaf Storbeck and Guy Chazan wrote: "Germany is to overhaul accounting regulation after the Wirecard collapse. The government will terminate its contract with the country's accounting watchdog, the Financial Reporting Enforcement Panel (FREP)... The power to launch investigations into companies' financial reporting would then be handed to BaFin, Germany's financial regulator." (Storbeck \& Chazan, 2020)

FREP was recently created and lightly staffed. Olaf Storbeck and Guy Chazan wrote; "FREP was founded in 2004 in response to the Enron accounting scandal but has only 15 employees and a small annual budget of $€ 6$ m... Under German law, BaFin could ask FREP to open a probe into a company's financial reporting but has no sway over the actual process. The Bonn-based regulator needs to wait for the result of a FREP probe before it can start its own investigation. BaFin in early 2019 asked FREP to start a probe into Wirecard after the Financial Times (FT) reported accusations by whistleblowers of accounting manipulations, according to people briefed on the matter. However, only one investigator at FREP has been working on the case and little progress was made." (Strobeck \& Chazan, 2020)

FREP failure on EY had raised questions about reform. Olaf Strobeck and Guy Chazan wrote: “Jörg Kukies, Germany’s deputy finance minister, told the Financial Times: 'What the Wirecard affair has shown is that... self-regulation by the auditors doesn't work properly. So we will inevitably have to question whether the bodies that currently regulate the industry should continue to do so in their current form'." (Strobeck \& Chazan, 2020)

\section{Case Study Continued: Wirecard and Politics}

The Wirecard scandal impacted politics in Germany about proper regulation of stock markets. Guy Chazan and Olaf Storbeck wrote: "As a parliamentary investigation reaches its climax-with the appearance of Angela Merkel and Olaf Scholz this week-MPs are asking why Germany's establishment was taken in by the collapsed group. It was an innocuous question, posed shortly before midnight some nine hours into an exhausting parliamentary hearing 
into the Wirecard scandal. 'Did you ever actually own Wirecard shares?' Cansel Kiziltepe, the Social Democrat MP, asked Ralf Bose, head of Germany's auditor watchdog Apas. His answer caused a political earthquake and brought an abrupt end to his more than 30-year career. A former partner at KPMG, Bose ran a government agency that is normally protected from public scrutiny by stringent secrecy laws. But those laws do not apply to the Bundestag's inquiry into Wirecard. Bose disclosed that he had bought and sold the company's stock while Apas was investigating its auditor EY. Just hours later the German government started to probe the transactions. And within a matter of weeks Bose had been fired. His late-night admission last December was one of the high points of an inquiry that has electrified Berlin's political class and led to a swath of resignations among top regulators and financial executives." (Chazan \& Storbeck, 2021)

The politics of the Wirecard scandal even reached the German Prime Minister. Guy Chazan and Olaf Storbeck wrote: "MPs will want to know why Merkel lobbied for Wirecard in China when reports about suspected fraud at the company had been in the public domain for months. Scholz will be asked to explain how BaFin, the financial regulator he oversees, not only failed to uncover the fraud but went after short-sellers and Financial Times journalists who first highlighted irregularities at the company. Scholz, who is running as the Social Democrats' candidate for chancellor in September's election, has placed the bulk of the blame on Wirecard's auditors... MPs have expressed amazement at the scale of the Wirecard lobbying operation, with its network of former police chiefs, ministers and spymasters, and at revelations that BaFin employees traded Wirecard shares while the company was under investigation. They also expressed shock at the fanciful stories cooked up by Wirecard lawyers alleging journalists' attempts to blackmail the company." (Chazan \& Storbeck, 2021)

\section{Expanded Analysis of Historical Case of Wirecard}

Next in Figure 4, we expand the analysis of the Wirecard event to include the understanding of operations and groups in the event.

We can now add into the analysis of the historical event of Wirecard the actions of the auditor Ernst \& Young Global Limited (EY) and the German regulator Federal Financial Supervisory Authority (BaFin) and the German auditors supervisory committee and the Financial Times investigatory reporting.

INDIVIDUALS-Markus Braun was the chief executive of Wirecard, having grown the company to international recognition. He was arrested in Munich on 25 June 2020. The President Felix Hufeld of the German regulatory agency BaFin defended Wirecard and later was forced to resign. The head of the German office of the auditor EY of Wirecard failed to perform proper audits of Wirecard from 2015 to 2018. Several employees or business associates of Wirecard assisted the fraudulent income reporting, such as Edo Kurniawan and R. Shanmugaratnam. 


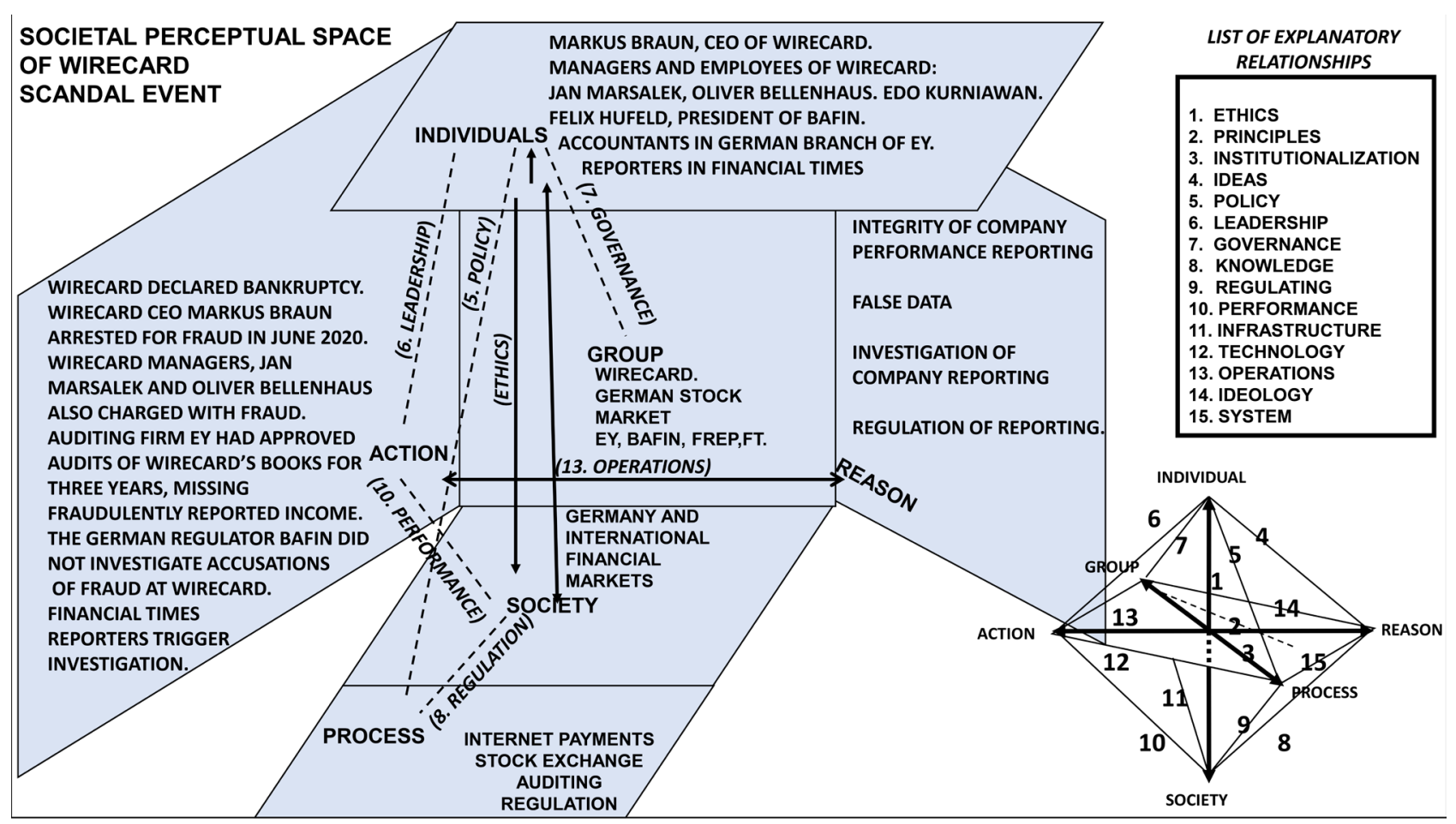

Figure 4. Adding auditing and regulation into the analysis of the Wirecard event.

And some Wirecard managers diverted Wirecard funds into shell companies, such as Jan Marsalek and Oliver Bellenhaus. Reporters in Financial Times triggered the investigation of fraud in Wirecard.

SOCIETY - The society was the German nation and the global business markets.

GROUP-The group in the event was a German company called Wirecard. Another group was the German office of the international auditing firm of EY which missed the fraudulent accounting information for three years. A third group involved in the event was the German regulatory agency of BaFin, which did not investigate any accusations of fraud in Wirecard and also defended Wirecard by forbidding shorting of its stock in the German stock market. The authority to regulate accounting firms in German was transferred from the Financial Reporting Enforcement Panel (FREP) to the BaFin. Another group in the event were newspapers with financial reporting, such as the Financial Times, which began uncovering the fraud.

PROCESS-The business process of Wirecard was intended to provide an electronic payment platform in different countries. But Wirecard could not gain a business license in Hong Kong to do business in China. Wirecard managers reported fraudulent revenues to make Wirecard's business operations to appear more profitable than they really were. EY's process was to do accurate audits of Wirecard's accounts to detect any fraud, but EY did not do proper audits. The regulatory process of BaFin was to investigate business practices for fraudulent activities. But BaFin failed to investigate Wirecard and instead defended its stock 
from short sellers.

REASON-Wirecard committed fraud when it told its auditor and German regulator that it had more business than it really had and also listed a billion dollars in profits it didn't have. The audit firm EY wanted to receive the auditing income from Wirecard and did not audit information in depth. The regulatory firm BaFin wanted Wirecard to be an example of a successful German firm in global digital commerce.

ACTION-A whistle-blower began an investigation in Wirecard and gave its findings to a newspaper, the Financial Times. This expose of Wirecard's fraud triggered Wirecard's bankruptcy. Markus Braun was accused of fraud in the operation of Wirecard and was arrested in Munich, Germany, on 25 June 2020. Wirecard managers, Jan Marsalek and Oliver Bellenhaus, were also charged with fraud. The auditing firm EY approved audits of Wirecard's books for three years, missing large amounts of fraudulently reported income. The German regulator did not investigate accusations of fraud at Wirecard.

With the additional information about the Wirecard scandal, we can now extend the analysis into the explanations between factors in the graphic depiction of the event.

6. LEADERSHIP - In the explanatory connection between the factors of the Individual and the Group, poor leadership was displayed by the CEO of Wirecard, by high-level managers of Wirecard, by auditors of the German division of EY, and by leaders of the German regulator BaFin.

1. ETHICS - In the explanatory connection between the factors of the Individual and Society: bad ethics was shown by the CEO in lying about non-existent business sales, bad ethics was shown by the top managers of Wirecard in stealing money and faking sales. Good ethics was shown by the whistle-blower and investigative reporters of the Financial Times in exposing the fraud.

13. OPERATIONS-In the explanatory connection between the factors of Reason and Action, poor business operations lost Wirecard customers and failed to gain business licenses in Asia countries essential to Wirecard's growth. Also poor operations in the auditor EY failed to investigate Wirecard's false claims about sales and profits.

10. PERFORMANCE-The Wirecard business revenues declined as business operations did not satisfy customers; and Wirecards' reported business growth in Asia was false, as Wirecard could not obtain a business license in China. Wirecard bankruptcy caused stock value to collapse.

12. TECHNOLOGY-Initially, German regulators were excited about Wirecard as high-tech company on the Internet. But Wirecard management did not improve technology to remain competitive. Wirecard failed to continually improve its software and processing system to keep its customers.

9. REGULATING-The German government financial market regulator, 
BaFin, did not perform any proper regulation of Wirecard to detect its business fraud.

5. POLICY - The failure of German regulation over its stock market led to calls for reform of regulation organization and operation.

7. GOVERNANCE-Government ministers established an investigation of the reasons for failure of regulation.

We see that the additional information in the historical case of Wirecard enabled us to analyze the event more deeply, in terms of explanatory relationships between event factors. There are a possible fifteen kinds of explanation in any event in a society's history; and some of the explanations may be more significant that others in explaining the event.

Analyzing a historical event in a society by means of a societal dynamics perceptual space enables the social scientist or historian to 'explain' the societal dynamics in the event-what significantly happened to alter societal stasis and why?

Failure of regulation in the case of Wirecard depended upon incompetence in operations, greed by top management, lying by top management, theft by mid-level managers, and lack of proper oversight by auditors and regulators.

\section{Literature Review}

As we have seen this empirical historical case of business fraud, Wildcard, it cannot be explained by any one social science discipline but required explanations from several disciplines. For example, the economics discipline while central to the case is insufficient to explain Wirecard fraud-because the fraud was not an "imperfection" in a perfect market theory but a corruption of business practice-deception and theft.

Accordingly, as we have been taking a cross-disciplinary approach in this research in a case of business fraud, and there are several literatures of the different schools of the social science relevant to the Wirecard case, which includes theories about markets and corporations. To use the Wirecard historical case as evidence for theory, we need to briefly review the relevant theories in the social science disciplines, including (a) regulatory economics, (b) economic markets, (c) corporate law, (d) organizational, and (e) auditing literatures.

\subsection{Regulatory Economics—Public Good}

Regulation is a topic which has been studied in several social science disciplines. It has long been a topic in economic theory, addressed under economic concept as "public good". Regulation has also been studied as a subfield of sociology as the sociology of law. Regulation has also been studied in the interdisciplinary social science area of "political economy".

In all views, there is agreement that formally "regulation" is enacted legislation which is administered to constrain rights and allocate responsibilities by 
participants in a societal order which is being regulated. In the topic of "administrative law", the term "rule-making" is used to characterize the process in which legislative and executive bodies create and implement rules-of-the-game. Legislature sets broad policy mandates by passing laws, and then executive agencies create and implement detailed regulations. In the United States enacted on June 11, 1946, the Administrative Procedure Act (U.S. Public Law. 79-404, 60 Statute. 237) established how administrative agencies of the U.S. federal government may propose and establish regulations and how federal courts may review agency regulatory decisions.

It is this view on "financial regulation" which we use here-defining the "rules of the game" for the economic activity. Proper rules allow economic activity to be beneficial to the public good rather than harmful. A properly regulated financial system controls the supply and price of money and credit to facilitate economic production, trade, and consumption. An improperly regulated financial system allows economic cheating, fraud, theft, inflation of monetary value, and financial instability.

Economists have used the term "private good" for a product/service is consumed only by a particular member of society and the term "public good" to indicate a product/service produced in a society which is shared by all members of society.

For example, Martin Wolf wrote: "Public goods are the building blocks of civilization. Economic stability is itself a public good. So are security, science, a clean environment, trust, honest administration, and free speech. The list could be far longer. This matters, because it is hard to secure adequate supply. The more global the public goods, the more difficult it is. Ironically, the better we have become at supplying private goods and so the richer we are, the more complex the public goods we need. Humanity's efforts to meet that challenge could prove to be the defining story of the century.... (now) a central element of debate is how to avoid extreme financial instability. Such instability is a public bad. Avoiding it is a public good." (Wolf, 2012)

Wolf defined the term: "For those unfamiliar with this terminology-What, is a public good? In the (economics) jargon, a public good is 'non-excludable' and 'non-rivalrous'. Non-excludable means that one cannot prevent non-payers from enjoying benefits. Non-rivalrous means that one person's enjoyment is not at another person's expense. National defense is a classic public good. If a country is made safe from attack everybody benefits, including residents who make no contribution. Again, enjoyment of the benefits does not reduce that of others. Similarly, if an economy is stable, everybody has the benefit and nobody can be deprived of it." (Wolf, 2012)

This is a positive view of a public-good, but not all economists have regarded the term as positive. Wolf wrote: "Public goods are an example of what economists call 'market failure'. The point is generalized in the language of 'externalities'-consequences, either good or bad, not taken into account by decision-makers. In such cases, Adam Smith's invisible hand does not work as one 
might like. Some way needs to be found to shift behavior. Public goods usually involve some state provision. Externalities usually involve a tax, a subsidy or some change in property rights. Free-market economists, such as Tyler Cowen of George Mason University, prefer the latter. But even that requires effective public action, if only via the apparatus of the law." (Wolf, 2012)

The issue in Wirecard is that German regulation of the German Stock mar-

ket did not detect nor stop the business fraud which Wirecard was exercis-

ing in the German Stock Market.

\subsection{Disequilibrium-Price Models of Financial Markets}

Another issue about financial markets is their periodic instability in economic history. A perfect market should be eternally stable, but this is not the case for real financial markets. And in financial regulation, one public good is to prevent collapses of financial systems.

For example, Martin Wolf wrote: "Economists have tended to assume that the market economy is inherently stable. If so, stability is supplied automatically. Unfortunately, this is not so. A free-market economy can expand credit without limit, at zero cost. Since money supply is simply the liability counterpart of private credit decisions, instability is baked in the economic cake. For this reason, economic stability is a public good we find quite hard to supply. The consequences of the repeated failure to do so can also be dire. Even the late Milton Friedman believed that government intervention, via the central bank, was needed to prevent long chains of banking collapses." (Wolf, 2012)

In financial market theory, Hyman Minsky proposed a "price disequilibrium theory" for describing the dynamics of financial bubbles (Minsky, 1982). He argued that "time" was an important dimension in a financial market, in addition to supply and demand. Minsky emphasized that, financial transactions of capital assets necessarily occur over time-with the rent currently paid and the possibility of a future sale of the asset.

In Figure 5, using a time-dimension, a graphic depiction of Minsky's description of financial transactions is shown. The dimension of time is necessary because the trade of capital assets (a financial market) has two economic values: current rent and future liquidity (Betz, 2014).

A temporal change can occur over the time of the financial transactions due to speculation in financial markets which traded capital assets. Minsky identified three levels of leverage in the financing. When the leverage in the loan is low enough to allow the "rent" from the income stream to fully service the loan (paying interest plus increments of the principle), then Minsky called this "hedge" (conservative) financing. When speculative traders purchase capital assets with leverage high enough to only allow servicing of interest but not principal payments, Minsky called this state for market financing as "speculative finance". Then on the sale of a capital asset by the trader, the trader must pay back the 


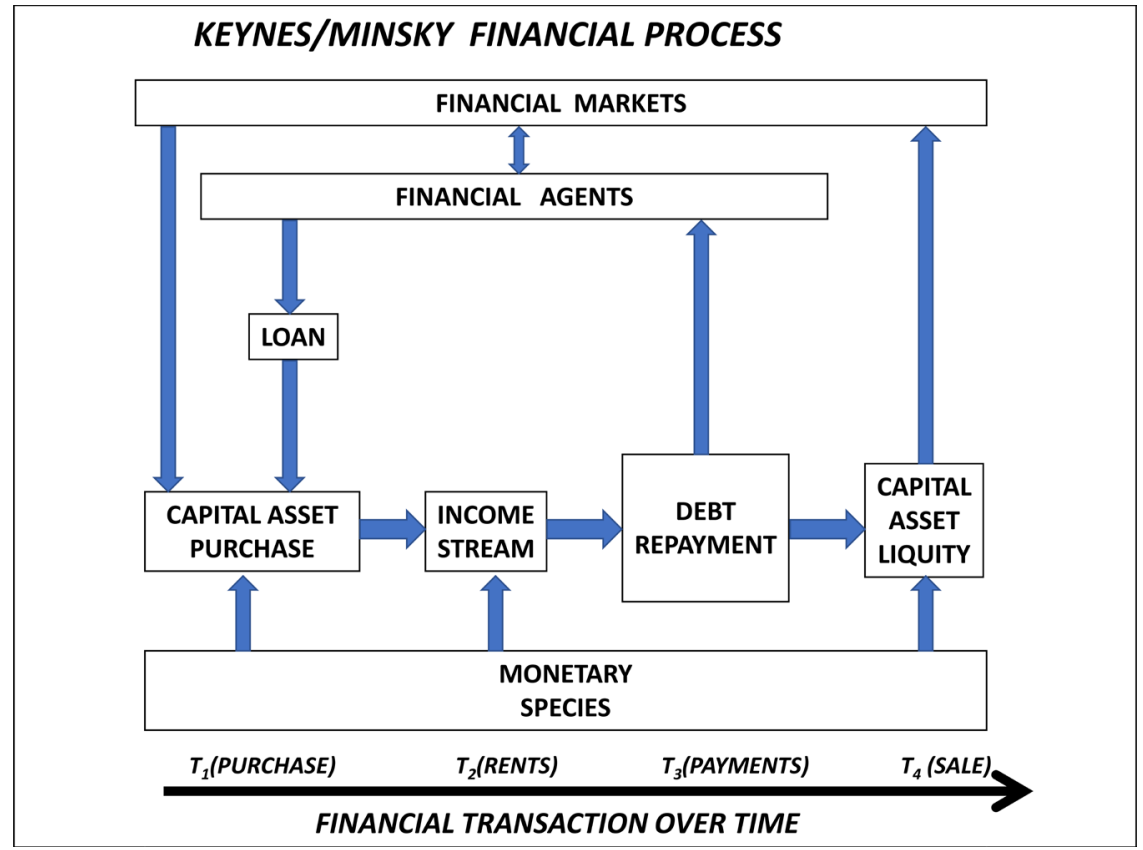

Figure 5. Financial transactions occur over time, with both rents and liquidity.

principal of the loan from receipts of the sale.

As long as a financial market rises, the speculative trading can be profitable. But when prices in a financial market rise speedily and traders purchase the capital assets with high leverage, then rents from the assets cannot service either the interest or the principal payments in the loan, then the trader must "flip" (immediately resell) the asset. This is the stage of a financial bubble, and Minsky called this "Ponzi financing". At this stage, the financial bubble will burst, as all Ponzi financed assets must be immediately flipped; and then the market for the capital assets collapses. In this model of financial transactions, "leverage" is a measure of how much is borrowed to purchase the financial asset. Leverage can increase profits which selling a purchased asset. But too much leverage in a financial market can crash the market.

Figure 6 depicts how the Minsky stages of financing in a financial bubble can occur over time-by adding a third dimension of time to the two-dimensions (price and quantity) in a market supply-demand curve for price equilibrium-shown here as the U.S. stock market during the dot.com bubble (Betz, 2014).

Over time from a period at $\mathrm{T} 1$ to a later time of $\mathrm{T} 2$, prices in a financial market price can move up into the price-disequilibrium of a financial bubble. And in the figure, one can see that stock market chart (covering the time of a financial bubble) can be pasted upon the graphic plane of Price-Time, because a stock market chart depicts the prices in the market over time.

In U.S. economic history, financial markets have experienced disequilibrium instabilities. In 2000, a private-credit market instability occurred in the "dot-com bubble" of the U.S. stock market. In 2007, a private-credit market instability occurred in the "mortgage-derivative bubble" of the U.S. 


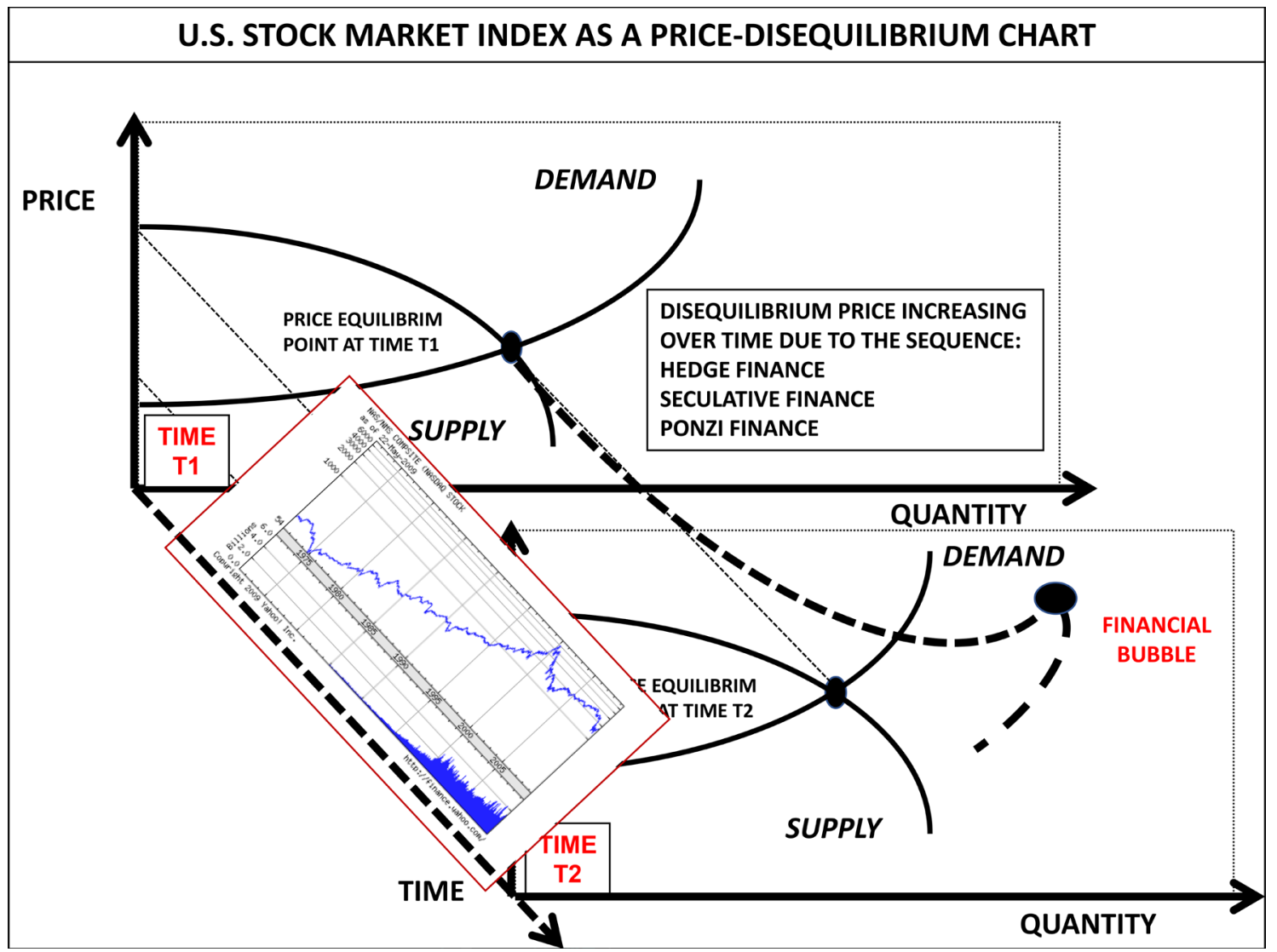

Figure 6. Financial market supply-demand curve over time-financial bubbles.

Wall Street sector, threatened to shut down the U.S. financial system.

The issue in Wirecard was that in the regulation of the German Stock Market, the German regulator had become enthused about the market success of Wirecard in attracting investment and then tried to stop investigations of fraud into the Wirecard. The German regulator stopped short-selling of Wirecard stock because of fear the German Stock Market might crash.

However, Wirecard's failure did not cause the German stock-market to crash. It was an isolated incident, limited to Wirecard itself. This failure was of a single company's fraud and not due to excessive leverage in the market. Some market failures are due to excessive leverage; and some to corruption. As financial market "imperfections", both Minsky-type excessive leverage and business corruption are possible market flaws. For stable financial markets, both types of flaws should be prevented by regulation.

\subsection{Corporate Law}

Corporate law depicts the legal status of the concept of a "corporation"; and securities regulation describes the legal context for the exercise of corporations-in raising capital and making such equity financially liquid.

Luca Enriques, Gerard Hertig, Reinier Kraakman and Edward Rock wrote: "Corporations are formidable tools for raising finance from the public. The core 
features of corporate law include limited liability and transferability of shares make corporations highly effective... Yet raising external capital exacerbates problems... Investors need protection from the risk or fraudulent or opportunistic behavior on the part of issuers... The body of rules, commonly referred to as 'securities law' or securities regulation' supports corporations in their efforts to raise external capital.” (Kraakman et al., 2017)

The issue in Wirecard was that neither the auditor nor the government regulator protected investors against loss of investment-due to the fraud in Wirecard by corporate executives.

One of the responsibilities of securities regulation is to ensure that corporations publish honest and sufficient information about operations. Luca Enriques, Gerard Hertig, Reinier Kraakman and Edward Rock wrote: "The case of mandatory disclosure assumes that firms will not disclose sufficient or sufficiently comparable information, unless they are required to do so... There are the familiar agency problems within corporations. Corporate insiders often prefer to suppress bad news: managers may do so to obtain higher compensation or to retain their jobs; shareholders may gain from silence by selling their shares at a higher price. Sensitive disclosures might damage any given firm in the markets... Another justification for mandatory disclosure is the value of standardization (of information), improving comparability (of corporate performance)." (Kraakman et al., 2017)

In the case of Wirecard, we saw that mandatory disclosure of performance was avoided by Wirecard management, and its auditing firm failed to learn the truth about Wirecard.

Luca Enriques, Gerard Hertig, Reinier Kraakman and Edward Rock cite some empirical evidence for the importance of mandatory disclosure: "Recent empirical literature supports the conventional view that publicly traded firms under-report information, especially negative information, if disclosure in not mandated... One study concluded that more extensive disclosure requirements, coupled with stricter enforcement mechanisms, significantly lowered the cost of equity capital (Hail \& Leuz, 2006)... Another found that stricter securities laws within the European Union, coupled with effective enforcement, were associated with improved liquidity." (Christian, Hail, \& Leuz, 2016; Kraakman et al., 2017)

The case of Wirecard is a historical study which empirically demonstrates the need for mandatory disclosure by corporations.

To emphasize again, the two basic theoretical concepts underlying the idea for a firm as a "corporation" are (1) "limited liability" for investors and (2) "entity shielding" for the firm. Henny Hansmann, Reinier Kraakman, and Richard Squire wrote: "Organizational law empowers firms to hold assets and enter contracts as entities that are legally distinct from their owners and managers. Legal 
scholars and economists have commented extensively on one form of this partitioning between firms and owners: namely, the rule of limited liability that insulates firm owners from business debts. But a less-noticed form of legal partitioning, which we call 'entity shielding', is both economically and historically more significant than limited liability. While limited liability shields owners' personal assets from a firm's creditors, entity shielding protects firm assets from the owners' personal creditors (and from creditors of other business ventures), thus reserving those assets for the firm's creditors." (Hansmann, Kraakman, \& Squire, 2005-2006)

Using fraudulent business reporting, Wirecard had no assets to protect, but the limited liability reduced the costs to the investors of only the loss of their investments in Wirecard.

As another depiction of the "firm" in corporate law, Hart described the relationship between investors (Principles) and managers (Agents). Oliver Hart wrote: "Principal-Agent Theory', an important development of the last fifteen years, addresses some of the weaknesses of the neoclassical approach. Principal-Agent Theory recognizes conflicts of interest between different economic actors, formalizing these conflicts through the inclusion of observability problems and asymmetries of information. The theory still views the firm as a production set, but now a professional manager makes production choices, such as investment or effort allocations, that the firm's owners do not observe." (Hart, 1989)

Wirecard illustrated some of the conflicts in "Principal-Agent theory', when the managers of Wirecard stole money from the company and caused bankruptcy and investors lost money due to by the principle agents (managers) thefts and unprofitable operations.

There is also the "stakeholder" theory of the firm, to broaden the concept of shareholders as the only benefactors of a firm. Thomas Donaldson and Lee E. Preston wrote: "The idea that corporations have stakeholders has now become commonplace in the management literature, both academic and professional... Stakeholders are persons or groups with legitimate interests in procedural and/or substantive aspects of corporate activity. Stakeholders are identified by their interests in the corporation, whether the corporation has any corresponding functional interest in them." (Donaldson \& Preston, 1995)

The business fraud in Wirecard benefited some managers of the firm but not stakeholders such as the shareholders nor customers.

Henry Hansmann and Reinier Kraakman wrote: "Much recent scholarship has emphasized institutional differences in corporate governance, capital markets, and law among European, American, and Japanese companies. Despite very real differences in the corporate systems, the deeper tendency is toward convergence, as it has been since the nineteenth century... Chief among these pressures is the recent dominance of a shareholder-centered ideology of corpo- 
rate law among the business, government, and legal elites in key commercial jurisdictions. There is no longer any serious competitor to the view that corporate law should principally strive to increase long-term shareholder value." (Hansmann \& Kraakman, 2000; Kraakman et al., 2017)

Wirecard was an international scandal, a global company operating across national lines-yet its regulation fell into only one nation, Germany, to oversee its honest operation, which, in fact, was dishonest on a world-wide scale.

There currently is no international organization to oversee reform for a possible international corporate law for global companies.

\subsection{Organization Theory}

The economist Oliver Hart summarized economic models about the "firm"; and the first model he described was a firm as a "production unit". Oliver Hart wrote: "Any discussion of theories of the firm must start with the neoclassical approach, the staple diet of modern economists. Developed over the last one hundred years or so, this approach can be found in any modern-day textbook; in fact, in most textbooks... Neoclassical theory views the firm as a set of feasible production plans. A manager presides over this production set, buying and selling inputs and outputs in a spot market and choosing the plan that maximizes owners' welfare. Welfare is usually represented by profit...” (Hart, 1989)

\section{Wirecard failed in increasing production as a "production unit".}

In management science, organization theory also views organizations as production units-goal directed and creating productive transformations to reach goals-also called an enterprise system. As shown in Figure 7, an enterprise system is an open-system, transforming inputs of resources to outputs of product sales. Also shown in the Figure is Michael Porter's model of a goal-directed-transformation, shown as a kind of "arrow" (Porter 1985).

Resources and Sales provide two strategic factors for the direct production transformations of a business operation. But there are also the strategic factors of Profits and Capital, both necessary to an enterprise system. These measure the factors for valuing business operations. Profit is a measure of business efficiency, the difference between prices and costs of sold products/services. Capital is a measure of the asset value of the business, the difference between investment and current stock value. Porter's value-added business model was only a two-factor model: Resources and Sales. Later, a more general form of business models was constructed in a four-factor model, by adding the strategic factors of Capital and Profit (Betz, 2018).

To construct a strategic business model of any enterprise, one can use the four strategic factors, either as inputs or outputs: Resources, Sales, Profits, Capital. How many types of "business models" can be constructed?

Logically, one can list all possible ( 2 by 2 types of enterprise open-systems) by 
taking all combinations of the four categories (resources, sales, profits, capital) two-at-a-time as inputs and as outputs. Ignoring the order of factors in a combination, one can construct six different models to describe a business, as shown in Figure 8.

The upper box lists the four strategic factors which can be used to construct a
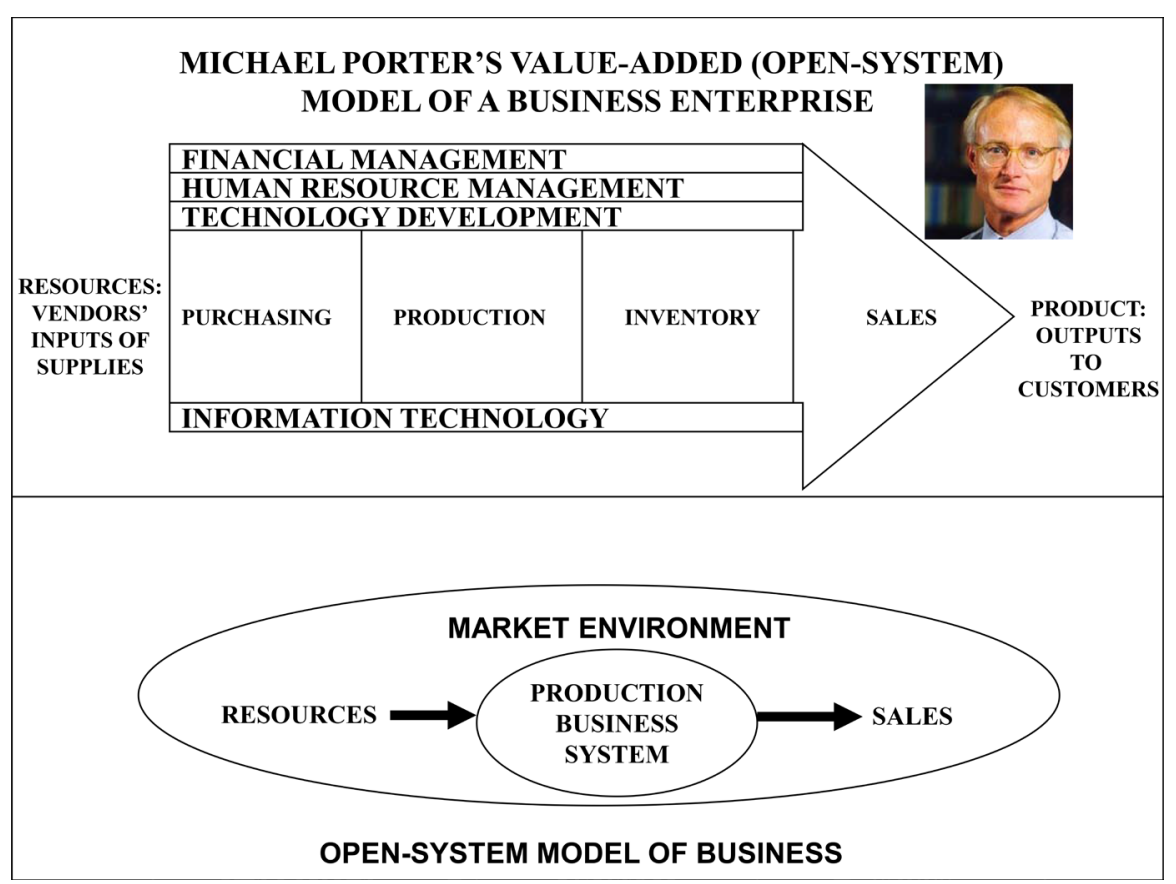

Figure 7. Porter's valued-added production model and open-system model of a production firm.

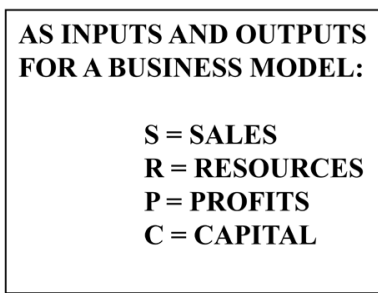

\begin{tabular}{|c|c|c|}
\hline \multicolumn{3}{|c|}{$\begin{array}{l}\text { LOGIC POSSIBILITIES } \\
\text { OF COMBINATIONS } \\
\text { OF INPUTS \& OUTPUTS, } \\
\text { TAKEN IN PAIRS }\end{array}$} \\
\hline$\underline{\text { IN }}$ & OUT & \\
\hline S\&R & P\&C & \\
\hline S\&P & $\mathbf{R} \& \mathrm{C}$ & \\
\hline S\&C & R\&P & \\
\hline $\mathbf{R \& P}$ & S\&C & \\
\hline$R \& C$ & S\&P & \\
\hline P\&C & S\&R & \\
\hline
\end{tabular}

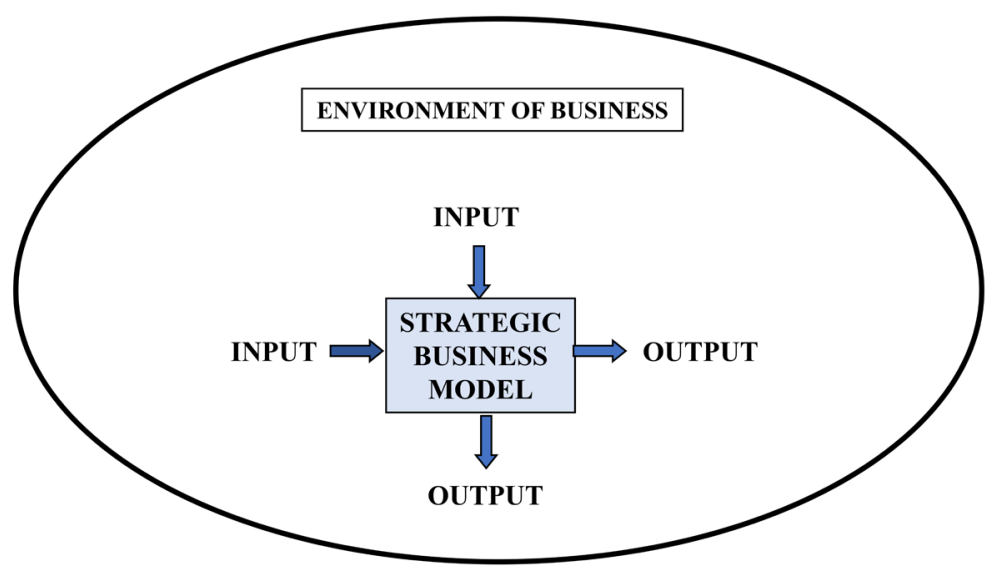

Figure 8. Four-factor model of a business enterprise system. 
strategic business model. The lower box takes them two at a time, as either inputs or outputs, and lists their six logical combinations (ignoring the order of the factors in a combination). The oval depicts the environment for a strategic business model with two inputs and two outputs.

Next Figure 9 depicts the six types of models possible from two-combinations of the four business factors.

Each type emphasizes a different focus of operations in a business. The strategic business model depicts how the four business factors of Capital Profits, Sales, and Resources operate as the "basics of a business". The four factors are needed to fully depict the basics of the value-adding of a business.

In the case of Wirecard, it represented itself to the world as a productive company, with resources and capital in and sales and profits out. But this was fraudulent, as modeled in Figure 10.

Wirecard failed to improve its software system Resources to deliver services to keep customers. Customers left and Sales declined and Profits vanished. Business acquisitions and expansions failed to bring in new customers. Some of the management even stole cash from Wirecard's Capital.

When finally investigated, it turned out that Wirecard was not a profitable operation. Olaf Storbeck wrote: "In the aftermath of Wirecard's collapse, it quickly became clear that the company's top echelon had spent years deceiving

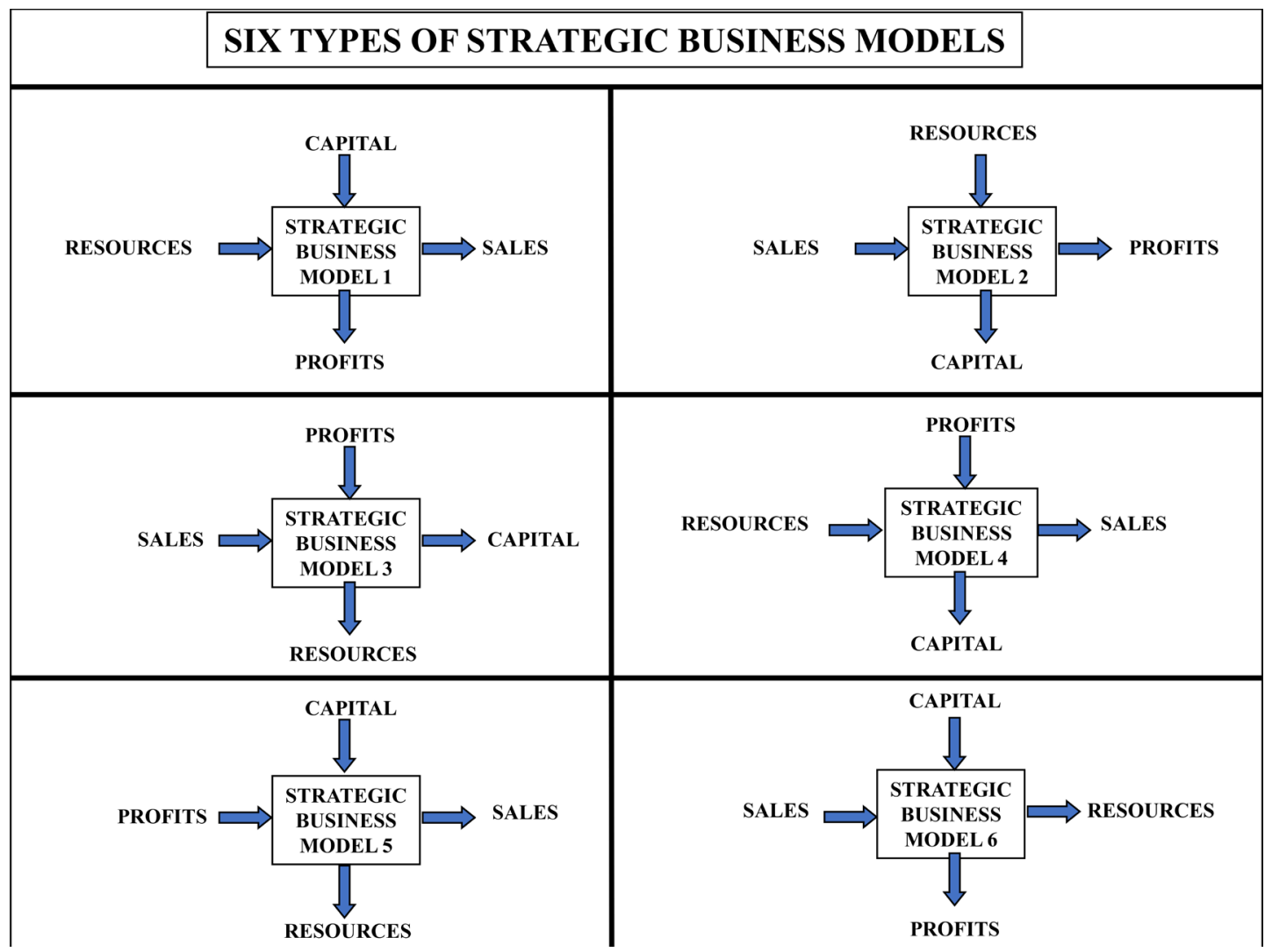

Figure 9. Six types of strategic business models of business enterprises. 


\section{STRATEGIC BUSINESS MODEL OF WIRECARD - ACTUAL OPERATIONS}

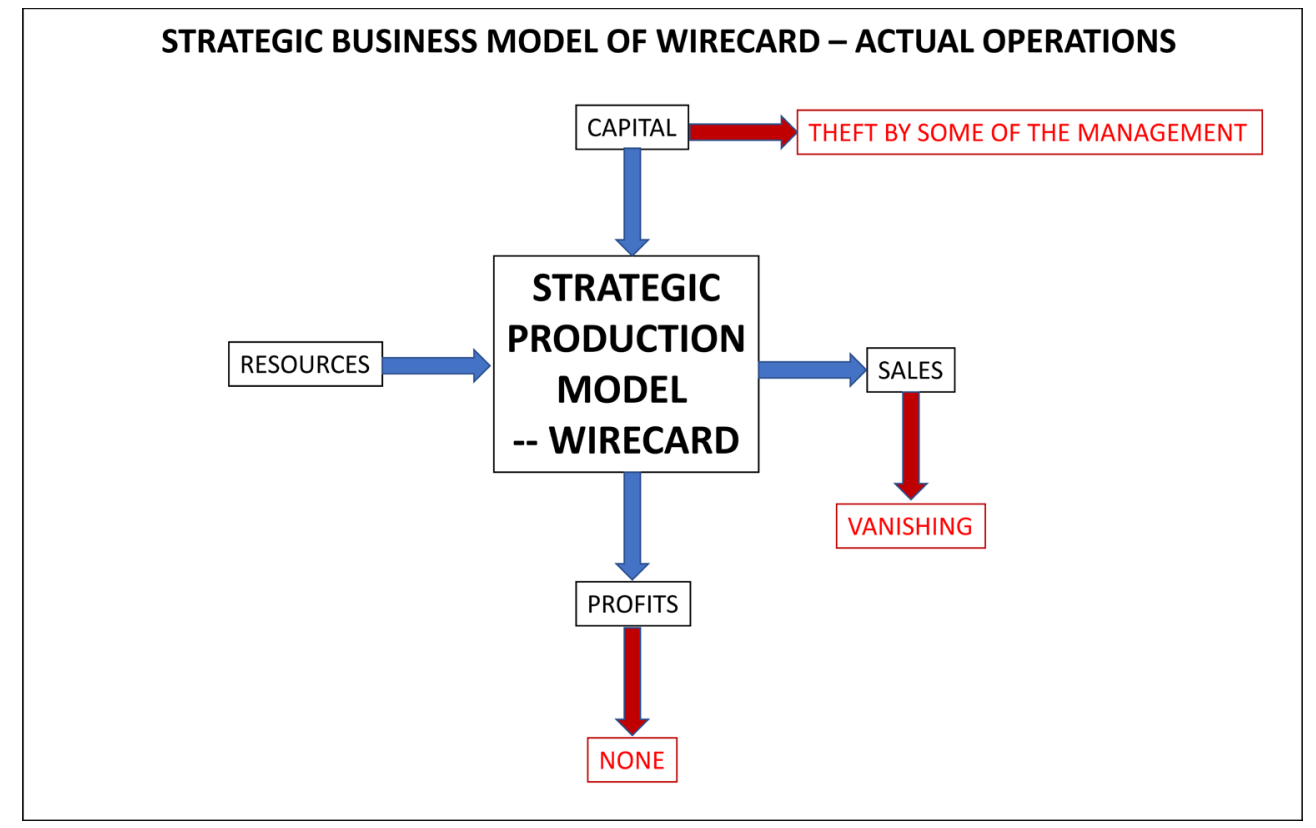

Figure 10. Production model of Wirecard in reality.

investors, regulators, auditors and large parts of its own staff. But what the internal communications also show is that the confused and disorderly scenes of its past few weeks were anything but an isolated incident. The documents and testimony reveal a company shaped by persistent mismanagement. Wirecard had presented itself as one of Germany's rare technological success stories; but on the inside, it was a chaotic, byzantine and often ineffective organization. In one of the most striking examples of the weakness of Wirecard's business, many of the operations that actually existed had been lossmaking for years, and some were heavily cash-burning. Even Alexander von Knoop, the company's chief financial officer, was not fully aware of the extent of the losses. In one instance, he was outraged when he learned in July 2019-some 18 months after his appointment-that Wirecard's relationship with Aldi, the supermarket chain it had boasted about being one of its clients, had generated close to $€ 5 \mathrm{~m}$ in losses over the previous three years. 'With all due respect for flagship clients, what is the plan to become profitable with Aldi in future?' he asked his underlings by email. He never received a convincing answer." (Storbeck, Financial Times June 25, 2021g)

In reality, Wirecard absorbed capital and did not make profits and advertised sales out that were not real nor improved resources. The company did not earn profits and consumed capital to pay for sloppy operations. Some managers even stole funds from Wirecard.

\subsection{Auditing Literature}

Corporate audits should provide an independent verification that the published account of the organization's performance. This "transparency" of information 
is intended to inform shareholders and other stakeholders about the performance of the corporate operations.

During the second half of the 20th century, eight large audit firms dominated the market: Arthur Andersen, Arthur Young, Coopers \& Lybrand, Deloitte Haskins and Sells, Ernst \& Whinney, Peat Marwick Mitchell, Price Waterhouse, and Touche Ross. But by 2002 (and with the collapse of Arthur Anderson), several mergers had left only four large firms: KPMG, Deloitte, EY, and PriceWaterhouseCoopers.

And regulatory oversight of these firms was only nationally based and quasi-governmental with light punishments for inaccurate audits. In the United States an oversight group was established in 2003. Max de Haldevang wrote: "The US Congress and Bush administration set up the PCAOB in 2003 after the collapse of Enron and WorldCom, Earth-shattering events in the corporate world that cost thousands of people their jobs and shareholders billions of dollars. At the heart of the scandals was Arthur Andersen, the former accounting giant, whose false audits helped the companies mislead the public on their financial health. Since auditors are paid by the companies they scrutinize, critics argue they have a built-in incentive to produce reports that please those companies-and, academic research shows, they lose business when they don't." (de Haldevang, 2019)

As to the performance of the audit firms, Max de Haldevang wrote: "The Big Four accounting firms bungled $31 \%$ of the most recent US audits analyzed by their quasi-governmental watchdog, the Public Company Accounting Oversight Board (PCAOB). Yet despite the abysmal findings, the oversight board-which the US government empowers to police the audit firms-has rarely taken action against them. In its 16-year history, the PCAOB has made only 18 enforcement cases against the foursome-KPMG, Deloitte, EY, and PriceWaterhouseCoopers-according to an investigation published recently by the Project on Government Oversight (POGO)... The government created PCAOB to audit the auditors and empowered it to punish them when they fail. Since it began its work, PCAOB has issued just $\$ 6.5$ million in fines on the Big Four, according to POGO. That's far short of the maximum total penalties the oversight board could have demanded the firms pay-some $\$ 1.6$ billion, POGO calculates. While the Big Four failed to properly audit their clients in $31.1 \%$ of cases examined by the PCAOB since 2009, the PCAOB has only disciplined them in $6.6 \%$ of those cases, including in actions also taken by the Securities and Exchange Commission (SEC), according to POGO data. (The SEC oversees the PCAOB and sometimes takes on high-profile cases involving auditors.)" (de Haldevang, 2019)

As the international economy has grown, the importance of honest auditing has also increased. For a company, an "internal audit" should report to management about the real performance of the company; and an "external audit" should verify this account of performance for the shareholders. For example, Jianjun Zou wrote: "As the economy develops faster and faster, the role of inter- 
nal audit in the company becomes more and more important, especially for corporate governance. The trend of globalization has intensified, and trade between countries is dense. It brings economic benefits to enterprises while increasing risks. In order to survive and develop, companies must face more challenges. On the one hand, the company must increase investment in internal governance management, and establish institutions such as shareholder meeting, board of directors, managerial level and board of supervisors, and the corporate governance structure is gradually standardized. On the other hand, the company's strengthening of internal audit can not only improve the company's operating conditions, but also timely discover problems within the company and effectively control them." (Zou, 2019)

In the Wirecard case, the bad audits by EY turned out to be not too unusual, considering, internationally, the poor oversight of auditing firms.

\section{Conclusion}

In this empirical research (which analyzed a historical case in modern economic history, the case of Wirecard in the second decade of the twenty-first century), we have tested the usefulness and validity of theories from several disciplines to explain the societal complexities in this case.

A major point of this research is the importance of cross-disciplinary social science-in order for the social sciences to be truly scientific. This research has shown that the social science analysis of a historical case in society may require theory from more than one social science discipline to explain the event and societal factors in the event. Thus cross-disciplinary research is vital to the social sciences-if they are to use history in a society as an empirical basis for the social sciences.

Methodologically, an analysis of historical events is a necessary method in the social sciences to scientifically verify and develop grounded theory-theory grounded in empiricism. We have seen in this empirical case in economic history, that there was evidence about several social science theories; and we have needed a cross-disciplinary social science approach to the research for explaining the event.

Any social science discipline focuses upon a single perspective (observational slice) through the complexity of society. Economics focuses upon market forces in a society. Law focuses upon legal relationships in a society. Political science focuses upon power relationships in a society. Sociology focuses upon group relationships in a society. Management science focuses upon leadership processes in a society. Anthropology focuses upon cultural processes in a society. Psychology focuses upon individuals' cognition within a society. The range of explanations in any historical societal of a society can go beyond explanation by any single social science discipline.

Starting with a basic economic theory about markets, we have seen in the case of Wirecard that corruption of a market was not a "market imperfection". In- 
stead, it had a more complex explanation as "corruption". Terms matter in constructing theory, the term "imperfection" connotes a very different meaning than does the term "corruption".

"Corruption" can happen from bad business practices which are hidden by dishonesty and which should be guarded against by government regulation, insisting on corporate transparency. In the financial market regulatory process, the identification of bad business practices is the primary function of the auditing process for the public inspection of the profitability of business operations. The regulatory requirement of business audits and publication of audits is the legal basis for transparency in valuing business equity.

Also "market corruption" does not only impact theory in the economics discipline, but also theory in other disciplines, such as law and management science and political science. To summarize the empirical impact of this case on social science theories, we restate the empirical evidence again.

German regulation of the German Stock market did not detect nor stop the business fraud which Wirecard was exercising in the German Stock market. In the regulation of the German Stock market, the German regulator became enthused about the market success of Wirecard in attracting investment and tried to stop investigations of fraud into the Wirecard-an enthusiast in a financial market as described by Minsky.

Using fraudulent business reporting, Wirecard had no assets to protect, also limited liability reduced the costs to the investors of only their investments in Wirecard.

Wirecard illustrates some of the conflicts in "Principal-Agent theory", when the managers of Wirecard stole money from the company and caused bankruptcy, with the investors losing money by the principle agents' (managers') bad operations.

The business fraud in Wirecard benefited some managers of the firm but not other shareholders.

Wirecard was an international scandal, a global company operating across national lines-yet its regulation fell into only one nation, Germany, to oversee its honest operation, which, in fact, was dishonest on a world-wide scale.

There currently is no international organization to oversee reform for a possible international corporate law for global companies.

Wirecard failed as a "production unit". Wirecard represented itself to the world as a productive company, with resources and capital in and sales and profits out. In reality, Wirecard absorbed capital and did not make profits and advertised sales out that were not real or improved resources. The company did not earn profits and consumed capital to pay for sloppy operations. Some managers even stole funds from Wirecard.

And historically, the action at Wirecard continued to unfold in 2021 and into 2022. In last 2021, Jack Ewing summarized the continuing action then about 
Wirecard: "The former chief executive of Wirecard was arrested Wednesday on new charges after prosecutors in Munich said they had uncovered evidence that the insolvent payments company had used false accounting to defraud creditors of $\$ 3.7$ billion. The accusations significantly increase the scale of the financial wreckage left by Wirecard, and will add to the pressure on German regulators and outside auditors who failed to uncover irregularities despite warning signs going back more than a decade. Markus Braun, the former chief executive, and two other former Wirecard executives were arrested early Wednesday after prosecutors 'significantly widened' their investigation of the company... The European Securities and Markets Authority, which oversees the European Union financial system, said last week that it would scrutinize Germany's banking and accounting regulators after Wirecard exposed possible shortcomings. Shareholders are suing EY, formerly known as Ernst \& Young, claiming the consulting firm did a bad job auditing Wirecard's books. EY has said it was also a victim of the fraud." (Ewing, 2020)

Also the Wirecard case has highlighted several roles in enabling markets to function properly, including: corporate leadership, regulators, auditors, financial reporters. Thus regulation theory needs to include all these kinds of roles in explaining how market should do function.

Modern newspapers play an important role (both in economics and in politics) in ensuring that organizational transparency in a society properly operates-and in providing important sources of historical archives.

Using societal events in modern history, the social science disciplines can find empirical observations about society, which can enlighten and validate theory-providing grounded theory in the social sciences.

\section{Conflicts of Interest}

The authors declare no conflicts of interest regarding the publication of this paper.

\section{References}

Alderman, L., \& Shuetze, C. F. (2020a, June 26). In a German Tech Giants Fall, Charges of Lies, Spies and Missing Billions. New York Times.

https://www.nytimes.com/2020/06/26/business/wirecard-collapse-markus-braun.html? searchResultPosition $=6$

Alderman, L., \& Schuetze, C. F. (2020b, June 23). Wirecard's Ex-CEO, Markus Braun, Is Arrested in Germany. New York Times.

https://www.nytimes.com/2020/06/23/business/wirecard-markus-braun.html?searchRe $\underline{\text { sultPosition }=1}$

Betz, F. (2011). Societal Dynamics. Springer. https://doi.org/10.1007/978-1-4614-1278-6

Betz, F. (2014). Disequilibrium Pricing Theory. Theoretical Economics Letters, 4, Article ID: 1500464 .

Betz, F. (2018). Strategic Business Models. Emerald Group Publishing.

Chazan, C., \& Storbeck, O. (2021, January 29). BaFin Bosses Forced Out over Handling of 
Wirecard Scandal. Financial Times.

https://www.ft.com/content/4f948457-678e-485c-92f7-2837064a5010

Christian, H. B., Hail, L., \& Leuz, C. (2016). Capital-Market Effects of Securities Regulation: Prior Conditions, Implementation, and Enforcement. Review of Financial Studies, 29, 2885-2924. https://doi.org/10.1093/rfs/hhw055

de Haldevang, M. (2019, September 10). Big Four Accounting Firms Bungle a Third of US Audits but Are Rarely Fined. Quartz.

https://qz.com/1705744/big-four-accounting-firms-are-bungling-a-third-of-us-audits/

Donaldson, T., \& Preston, L. E. (1995). The Stakeholder Theory of the Corporation: Concepts, Evidence, and Implications. The Academy of Management Review, 20, 65-91. http://www.jstor.org/stable/258887 https://doi.org/10.5465/amr.1995.9503271992

Ewing, J. (2020, July 22). Wirecard Ex-CEO Arrested on New Charges of Defrauding Banks. New York Times. (Updated December 7)

https://www.nytimes.com/2020/07/22/business/wirecard-ex-ceo-arrested.html?searchR esultPosition $=2$

Granville, K. (2020, June 25). Wirecard, Reeling from Accounting Scandal, Files for Insolvency. New York Times. https://www.nytimes.com/2020/06/25/business/wirecard-insolvency-bankruptcy.html? searchResultPosition $=4$

Hail, L., \& Leuz, C. (2006). International Differences in the Cost of Equity Capital: Do Legal Institutions and Securities Regulation Matter? Journal of Accounting Research, 44, 485-531. https://doi.org/10.1111/j.1475-679X.2006.00209.x

Hansmann, H., \& Kraakman, R. (2000). The End of History for Corporate Law. Georgetown Law Journal, 89, 439-468.

https://digitalcommons.law.yale.edu/cgi/viewcontent.cgi? article $=6067 \&$ context $=$ fss pa pers

Hansmann, H., Kraakman, R., \& Squire, R. (2005-2006). Law and the Rise of the Firm. Harvard Law Review, 119, 1335-1403. https://doi.org/10.2139/ssrn.873507 https://ir.lawnet.fordham.edu/cgi/viewcontent.cgi?referer=https://scholar.google.com/ \&httpsredir $=1$ \&article $=1068 \&$ context $=$ faculty scholarship

Hart, O. (1989). An Economist's Perspective on the Theory of the Firm. Columbia Law Review, 89, 1757-1774. http://www.jstor.org/stable/1122818 https://doi.org/10.2307/1122818

Krakkman, R., Armour, J., Davies, P., Enriques, L., Hansmann, H., Hertig, G., Hopt, K., Kanda, H., Pargendler, M., Ringe, W.-G., \& Rock, E. (2017). The Anatomy of Corporate Law (3rd ed.). Oxford University Press. https://doi.org/10.1093/acprof:oso/9780198739630.001.0001

McCrum, D., \& Palma, S. (2019, February 7). Wirecard: Inside an Accounting Scandal. Financial Times. https://www.ft.com/content/d51a012e-1d6f-11e9-b126-46fc3ad87c65

Mccrum, D., Palma, S., \& Storbeck, O. (2021, May 21). Wirecard Whistleblower Tells of Harsh Journey. Financial Times. https://digital.olivesoftware.com/Olive/ODN/FTUS/Default.aspx

Minsky, H. P. (1982). Can 'It' Happen Again? Challenge, 25, 5-13. https://doi.org/10.1080/05775132.1982.11470774

Palma, S., Storbeck, O., \& McCrum, D. (2020, August 10). Wirecard Agent Charged in Singapore over Fake Accounts. Financial Times. https://digital.olivesoftware.com/Olive/ODN/FTUS/Default.aspx 
Porter, M. (1985). Competitive Strategy. New York: The Free Press.

Storbeck, O. (2020, July 6). Wirecard's core Europe and US business was in the red for years. Financial Times. https://digital.olivesoftware.com/Olive/ODN/FTUS/Default.aspx

Storbeck, O. (2021a, February 4). BaFin Gave EU Watchdog Selective Briefing on Wirecard Short-Selling Ban. Financial Times. https://www.ft.com/content/5db3d0cd-35b4-42d5-9969-e506a7b0ca58

Storbeck, O. (2021b, March 24). Wirecard Fraud Started More than Decade Ago Former Executive Says. Financial Times. https://digital.olivesoftware.com/Olive/ODN/FTUS/Default.aspx

Storbeck, O. (2021c, April 10). Marsalek's Wirecard Deal Role in Spotlight. Financial Times. https://digital.olivesoftware.com/Olive/ODN/FTUS/Default.aspx

Storbeck, O. (2021d, April 19). EY’s Wirecard Audits Had Serious Flaws, Probe Reveals. Financial Times. https://digital.olivesoftware.com/Olive/ODN/FTUS/Default.aspx

Storbeck, O. (2021e, April 23). Wirecard Staff Removed Millions in Cash from HQ in Plastic Shopping Bags. Financial Times. https://digital.olivesoftware.com/Olive/ODN/FTUS/Default.aspx

Storbeck, O. (2021f, May 21-22). EY Audit Failings on Wirecard Laid Bare in 'Dynamite' Report. Financial Times. https://digital.olivesoftware.com/Olive/ODN/FTUS/Default.aspx

Storbeck, O. (2021g, May 28). EY’s Deutsche Bank Auditing Role in Danger after Wirecard. Financial Times. https://digital.olivesoftware.com/Olive/ODN/FTUS/Default.aspx

Storbeck, O., \& Chazan, G. (2020, June 28). Inside Wirecard AG. Financial Times. https://www.ft.com/content/e037d830-cfd8-4bca-853d-d49f48e67f13

Storbeck, O., Kinder, T., \& Palma, S. (2020, June 26). AG EY Failed to Check Wirecard Bank Statements for 3 Years. Financial Times. https://www.ft.com/content/a9deb987-df70-4a72-bd41-47ed8942e83b

Storbeck, O., Milne, R., \& Palma, S. (2021, May 18). Lithuanian Fintech under Scrutiny over Potential Role in Wirecard Fraud. Financial Times. https://digital.olivesoftware.com/Olive/ODN/FTUS/Default.aspx

Wolf, M. (2012). The World's Hunger for Public Goods. Financial Times, January 24.

Zou, J. (2019). On the Role of Internal Audit in Corporate Governance. American Journal of Industrial and Business Management, 9, Article ID: 89782. https://www.scirp.org/pdf/AJIBM 2019010915021852.pdf https://doi.org/10.4236/ajibm.2019.91005 